\title{
A robust vegetation-based elevation transfer method for reconstructing Arctic polygon mire palaeo-microtopography
}

\author{
Annette Teltewskoi $^{\mathrm{a}, *}$, Dierk Michaelis ${ }^{\mathrm{a}}$, Lutz Schirrmeister ${ }^{\mathrm{b}}$, Hans Joosten $^{\mathrm{a}}$, Ulf Schiefelbein ${ }^{\mathrm{c}}$, \\ Michael Manthey ${ }^{\mathrm{a}}$ \\ a Institute of Botany and Landscape Ecology, Greifswald University, partner in the Greifswald Mire Centre, Soldmannstraße 15, D-17487 Greifswald, Germany \\ ${ }^{\mathrm{b}}$ Department of Permafrost Research, Alfred Wegener Institute Helmholtz-Centre for Polar and Marine Research, Telegrafenberg A45, D-14473 Potsdam, Germany \\ ${ }^{\mathrm{c}}$ Blücherstr. 71, D-18055 Rostock, Germany
}

\section{A R T I C L E IN F O}

\section{Keywords:}

Active layer

Fossilization

Quantitative reconstruction

Macrofossil

Pollen

Permafrost

\begin{abstract}
A B S T R A C T
The reconstruction of past environments by means of macrofossil and pollen analysis is commonly based on the modern ecological preferences of the taxa that may have produced these fossils. Here we present a modelling approach, in which we use modern vegetation-surface height relationships to quantify past surface heights in an Arctic ice-wedge polygon mire. Vegetation composition and ground surface height (GSH) were assessed in a polygon mire near Kytalyk (Northeastern Siberia). Cluster analysis revealed five plant communities, which are clearly separated with respect to ground surface height, frost surface height and coverages of open water and vegetation. Based on the composition of modern vegetation we constructed two sets of potential fossil types (plant macrofossils and pollen), an extensive one and a more restricted one to reflect different conditions of preservation and recognisability. We applied Canonical Correspondence Analysis to model the relationships between potential fossil types and measured GSH. Both models show a strong relationship between modelled and measured GSH values and a high accuracy in prediction. Finally, we used the models to predict GSH values for Holocene peat samples and found a fair correspondence with expert-based multi-proxy reconstruction of wetness conditions, even though only a minor part of the encountered fossils were represented in the GSH models, illustrating the robustness of the approach. Our approach can be used to reconstruct palaeoenvironmental conditions in a more objective way and can serve as a template for further palaeoecological studies.
\end{abstract}

\section{Introduction}

Over the past three decades, temperatures in the Arctic have increased by about $1{ }^{\circ} \mathrm{C}$ per decade, being significantly more than the global trend (Christensen et al., 2014; NOAA, 2015; Streletskiy et al., 2015; Huang et al., 2017). Circumpolar soils contain almost half of the world's soil carbon (Hugelius et al., 2014) and thawing of these soils may result in substantial greenhouse gas emissions, which may feedback on further global warming (Tarnocai, 1999; Dutta et al., 2006; Koven et al., 2011). Ice-wedge polygon mires constitute the most concentrated occurrences of near-surface soil carbon in the Arctic.

Permafrost dependent ice-wedge polygon mires occur extensively in the lowlands of Northeast Russia, North Alaska and North Canada (Fig. 1). They develop as a result of multi-year soil frost cracking and subsequent ice-wedge growth, leading to a polygonal pattern of low and high surface relief elements (French, 2007; Minke et al., 2007), which differently exchange $\mathrm{CO}_{2}$ and $\mathrm{CH}_{4}$ with the atmosphere (Wainwright et al., 2015; Vaughn et al., 2016; Grant et al., 2017).

The effects of global warming on the greenhouse gas exchange of polygon mires are hard to predict due to the complex interplay of external and internal forcing, direct and indirect effects and positive and negative feedback mechanisms determining surface relief dynamics (Donner et al., 2012; Godin et al., 2016; Liljedahl et al., 2016). Removal of low shrub vegetation in the Kytalyk area (NE Siberia), for example, initiated thawing of ice-rich permafrost, altered the originally dry elevated patches into waterlogged depressions, and changed the plots from a methane sink into a methane source within five years (Nauta et al., 2015). Also palaeoecological studies show extremely rapid changes in polygon mire relief triggered by changes in climate/weather, with counterintuitively - permafrost expanding in warmer and collapsing in colder years (De Klerk et al., 2011; Gao and Couwenberg, 2015). Palaeoecological studies are still relatively rare and may shed more light on the complex dynamics of polygon mires and contribute to a better understanding of recent states and future fates of these vast carbon-rich

\footnotetext{
* Corresponding author.

E-mail address: a.teltewskoi@posteo.de (A. Teltewskoi).
} 


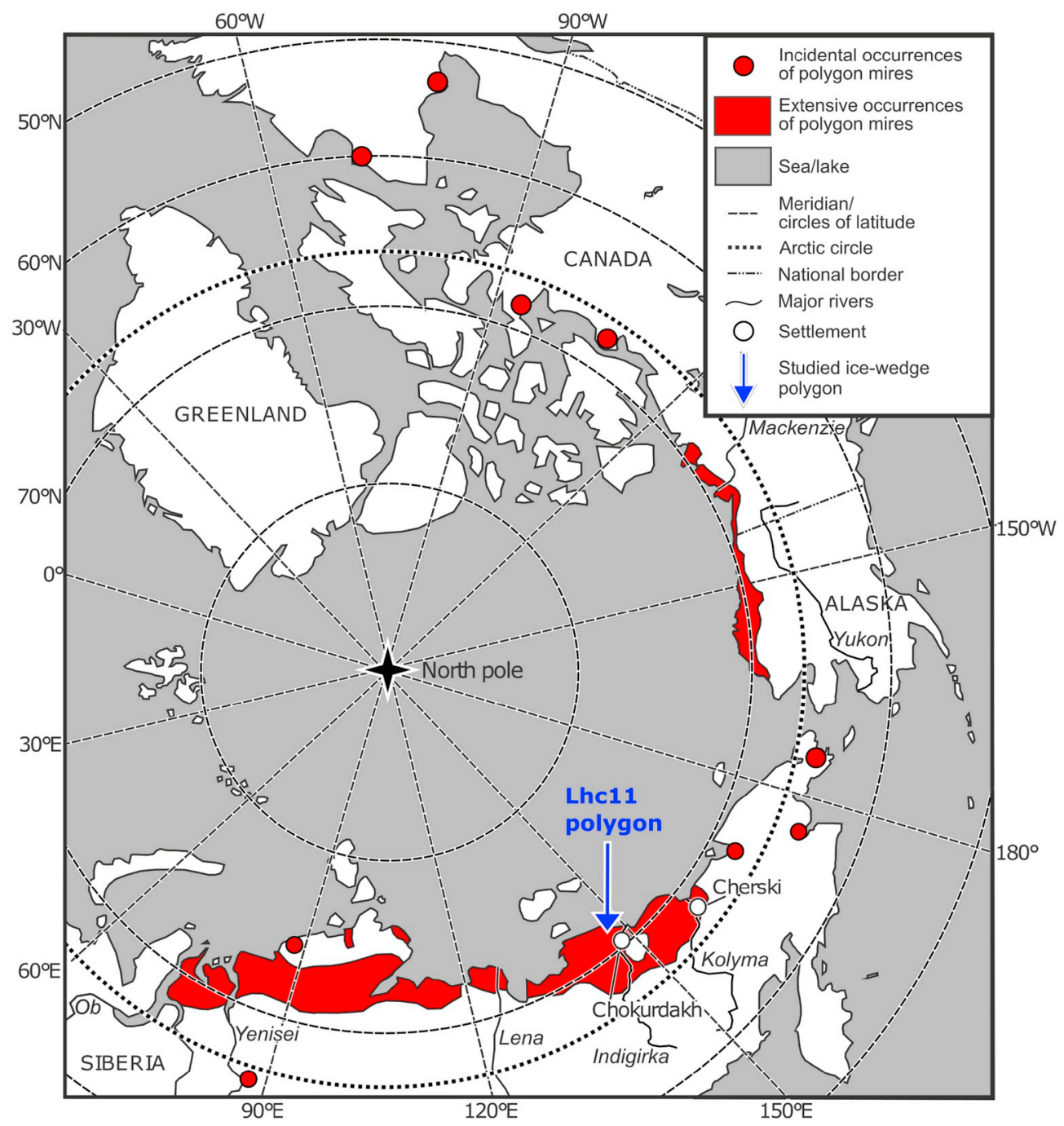

Fig. 1. Circumpolar distribution of polygon mires with the location of the Lhc11 polygon.

Modified after De Klerk et al. (2014).

ecosystems under climate warming.

The reconstruction of former surface wetness, i.e. of the height of microrelief elements is crucial in these studies. This relief/wetness is generally reconstructed using plant fossils, which are attributed to wetness classes or to a relative position on a conceptual dry-wet gradient (Ellis and Rochefort, 2004; De Klerk et al., 2011; Zibulski et al., 2013; Fritz et al., 2016; Teltewskoi et al., 2016). Better understanding of polygon dynamics and former carbon and greenhouse gas fluxes requires, however, more detailed and better quantified palaeomicrotopographical information. This paper aims at developing, a new calibration approach to reconstruct past ground surface heights (GSH) in polygon mires from palaeo-macrofossil and pollen data, using modern ground surface height measurements and constructed 'potential fossil types' derived from modern vegetation.

\section{Methods}

\subsection{Site selection and description}

We selected ice-wedge polygon Lhc11, because the polygon (with an age of $>4000$ years, Teltewskoi et al., 2016) represents an advanced phase of polygon development featuring wide spans of ground surface and frost surface heights.

Polygon Lhc11 $\left(70^{\circ} 49^{\prime} 50^{\prime \prime} \mathrm{N}, 147^{\circ} 28^{\prime} 52^{\prime \prime}\right.$ E) is located near the
Kytalyk scientific station at the Berelekh River, $30 \mathrm{~km}$ northwest of the settlement Chokurdakh (Figs. 1, 2). Mean annual air temperature is $-14.2^{\circ} \mathrm{C}$, mean July temperature $+9.7^{\circ} \mathrm{C}$, mean January temperature - $36.6^{\circ} \mathrm{C}$, mean annual precipitation $350 \mathrm{~mm}$ (meteorological data Chokurdakh, World Meteorological Organization, station no. 21946). Permafrost temperature in the region is -4 to $-6{ }^{\circ} \mathrm{C}$ (Rivas-Martínez, 2007), permafrost thickness $200-300 \mathrm{~m}$ (Geocryological Map, 1991) or even $>500 \mathrm{~m}$ (Iwahana, 2006, 2001). The landscape around Kytalyk consists of flood plains, low hills composed of late Pleistocene ice-rich deposits (Yedoma Ice Complex), and alas depressions with thermokarst lakes (Van der Molen et al., 2007; Petrescu et al., 2008; Tumskoy and Schirrmeister, 2012). The regional vegetation consists of tussock-sedgedwarf shrub-moss tundra (CAVM Team, 2003).

Polygon Lhc11 is located in an alas at a distance of $300 \mathrm{~m}$ to a Yedoma hill and $600 \mathrm{~m}$ to Berelekh River (Fig. 2). The centre of Lhc11 $(26 \times 21 \mathrm{~m})$ consists of a small, shallow wet depression of about 5 metre diameter and $10 \mathrm{~cm}$ depth. The centre is surrounded by dry ridges of maximally $40 \mathrm{~cm}$ high with a deeply-thawed ridge part of $30 \mathrm{~cm}$ depth, a so called "hydrological window" (Donner et al., 2012), in the south-western corner. Deep and broad wet troughs of maximally $59 \mathrm{~cm}$ deep separate Lhc11 from ridges/degraded ridges of adjacent polygons (Fig. 3).

The vegetation of polygon Lhc11 is dominated by Carex concolor (Carex aquatilis ssp. stans), Eriophorum angustifolium, Carex chordorrhiza, 

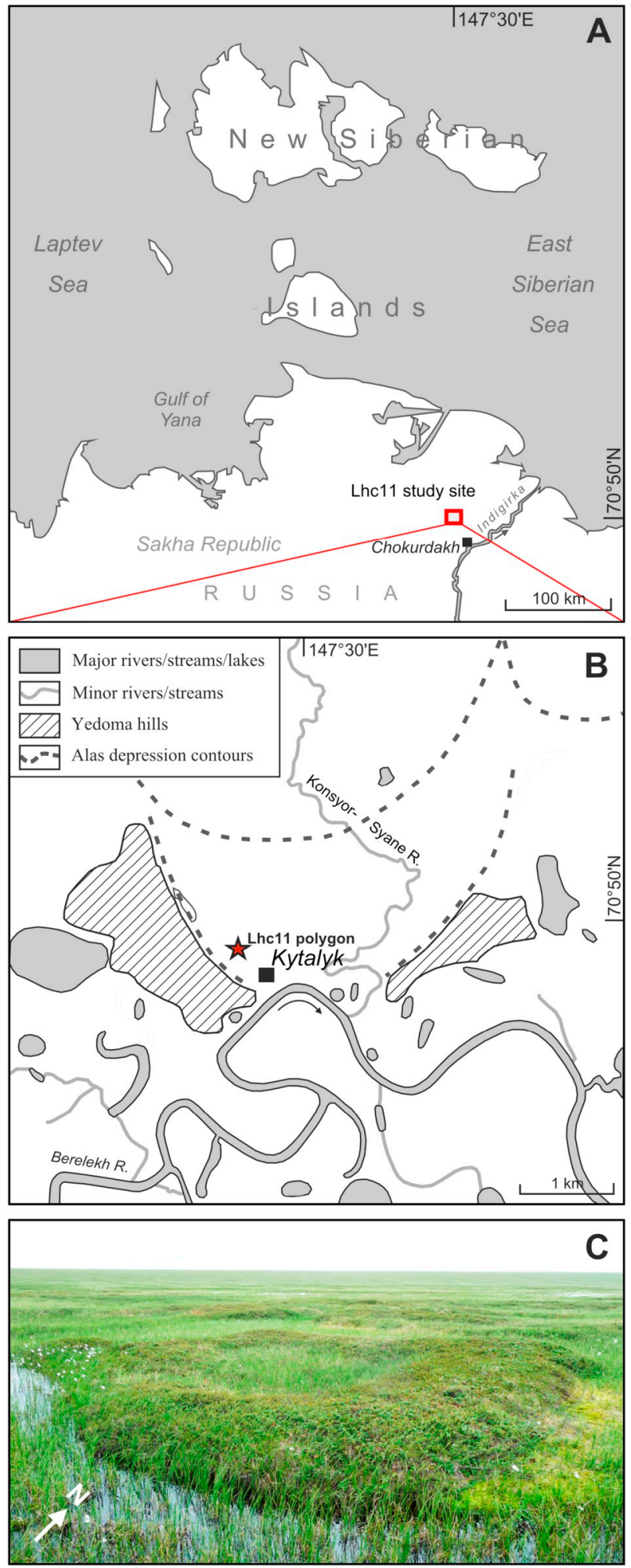

Fig. 2. Study area. (A) Ice-wedge polygon Lhc11 is located $30 \mathrm{~km}$ northwest of the settlement Chokurdakh in NE Siberia (B) near the research station Kytalyk close to the Berelekh River - indicated are the most important landforms. Modified after De Klerk et al. (2014). (C) A photograph of ice-wedge polygon Lhc11.

Carex rotundata, Sphagnum squarrosum, Sphagnum flexuosum, Utricularia ochroleuca, Utricularia vulgaris and Potentilla palustris in the depressions, and Betula exilis, Ledum decumbens, Rubus chamaemorus, Salix spp., Vaccinium vitis-idaea, Poaceae, Dicranum acutifolium, Aulacomnium palustre, Ptilidium ciliare and several lichen taxa on the ridges (Beermann et al., 2015; De Klerk et al., 2014).

\subsection{Vegetation analysis}

During field work in July 2011 (Teltewskoi et al., 2012) vegetation composition was recorded in a grid of $1 \times 1 \mathrm{~m}$ over an area of $26 \times 21 \mathrm{~m}$ (546 plots, Fig. 3), using a wooden frame of $1 \times 1 \mathrm{~m}$, divided into 25 smaller quadrats. Cover of plant species, total vegetation, litter and water was estimated following Londo (1976). Vascular plants were identified using Polunin (1959), Tolmachev (1974) and Rothmaler (2002) and named after Czerepanov (1995). Mosses were identified using Abramova et al. (1961), Frahm and Frey (1992), Frey et al. (1995), Michaelis (2011) and Smith (1980) and named after Michaelis (2011, peat mosses), Ignatov et al. (2006, other mosses) and Konstantinova and Bakalin (2009, liverworts). Lichens were identified using chemo-taxonomical markers (Orange et al., 2001) and Ahti and Stenroos (2013), Golubkova et al. (1978, 1996), Kärnefelt (1979, 1986), Kärnefelt and Thell (1996), Kärnefelt et al. (1993), Vitikainen (1994), Thomson (1984) and Zhurbenko et al. (2005), and named after Ahti and Stenroos (2013, Cladonia) and Urbanavichus (2010, other lichens).

Coverages of total herbs, shrubs, brown mosses, Sphagnum, liverworts and lichens were estimated by summation of the cover of the relevant individual species. The vegetation relevés were clustered to unranked communities with the function isopam (no fixed cluster number, Bray-Curtis distance of the full floristic composition and cover estimates in percentage) of the $\mathrm{R}$ package isopam (Schmidtlein et al., 2010). Indicator species were identified using the function multipatt of the R package indicspecies (De Caceres and Jansen, 2016). The latter is an extension of the species indicator value analysis of Dufrene and Legendre (1997) and allows identification and testing of indicator species characteristic for groups of communities (De Caceres et al., 2010). A vegetation map was constructed using the software QGis version 1.8.0 "Lisboa" and modified with drawing software Inkscape 0.91 (INKSCAPE Draw Freely, 2015). Boxplots and descriptive statistics were generated with SPSS (SPSS Statistics ver. 16).

\subsection{Microtopographical height measurements}

Heights were measured in the centre of all plots relative to a horizontal reference level, constructed over the study site with strings fixed at wooden sticks and using a water-level tube (Teltewskoi et al., 2012). For later analysis the reference level was conceptually moved $200 \mathrm{~cm}$ deeper to allow expressing elevated spots with higher values than lower spots (Fig. 4).

Ground surface was defined as the surface of living moss or the surface of bare peat. Frost surface height was determined by pushing a rod into the unfrozen soil down to the frost table. Thaw depth is the difference between GSH and frost surface height (Minke et al., 2009). Three-dimensional terrain models of the study site (Fig. 3) were generated with Surfer 11 (Golden Software, 2011) and modified with the drawing program Inkscape 0.91 (INKSCAPE Draw Freely, 2015).

\subsection{Potential fossil types}

For all encountered plant species the potential for fossilization and fossil identification was estimated, using experiences from earlier studies (De Klerk et al., 2009, 2011, 2014; Teltewskoi et al., 2016; Zibulski et al., 2013) and determination literature (Table 1). Potential fossils were subdivided into potential (i) pollen/spores types, given that Arctic pollen deposition mainly reflects short-distance vegetation patterns (De Klerk et al., 2009, 2014), (ii) belowground macrofossils, (iii) vegetative aboveground/near surface macrofossils and (iv) generative aboveground macrofossils. Belowground macrofossils (class ii) were excluded from GSH modelling, because of the unclear chronostratigraphy of the 


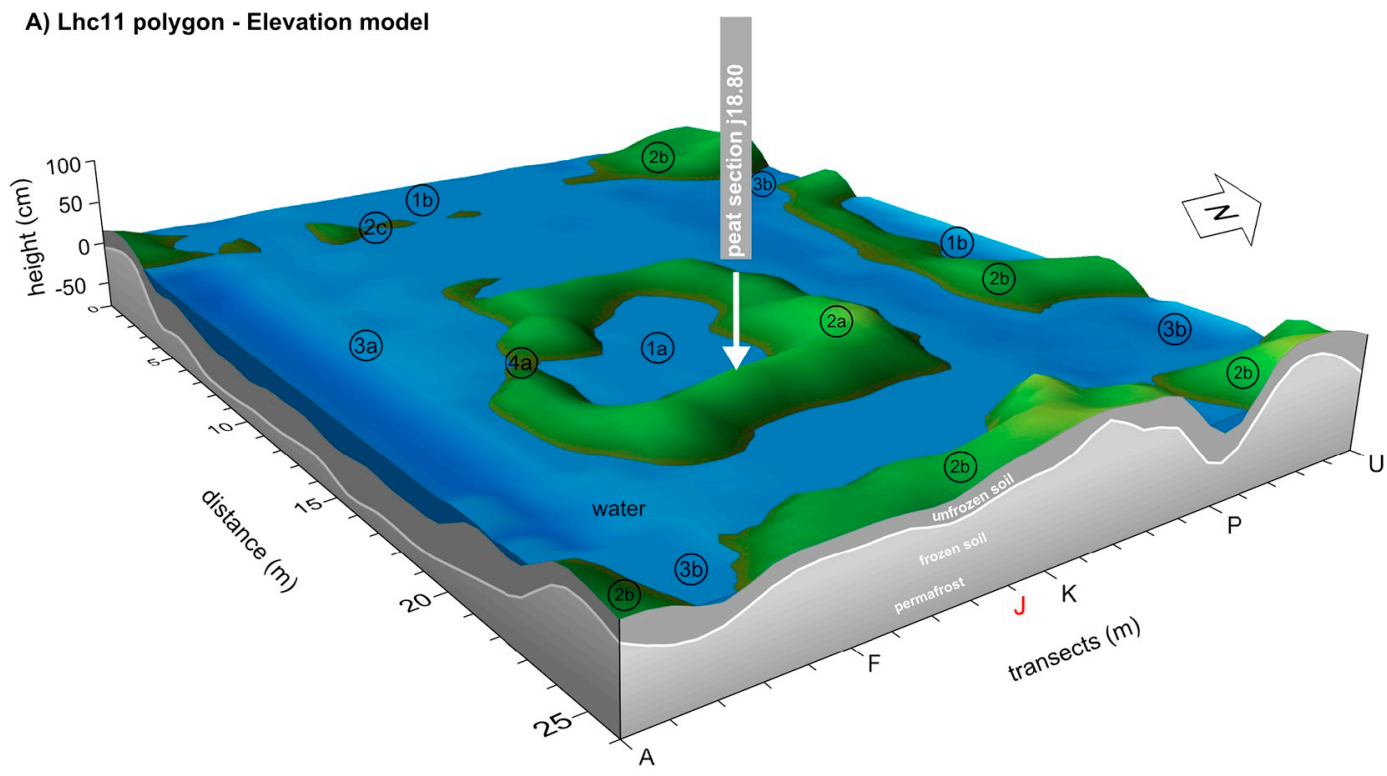

\section{B) Lhc11 polygon - Ground surface elevation}

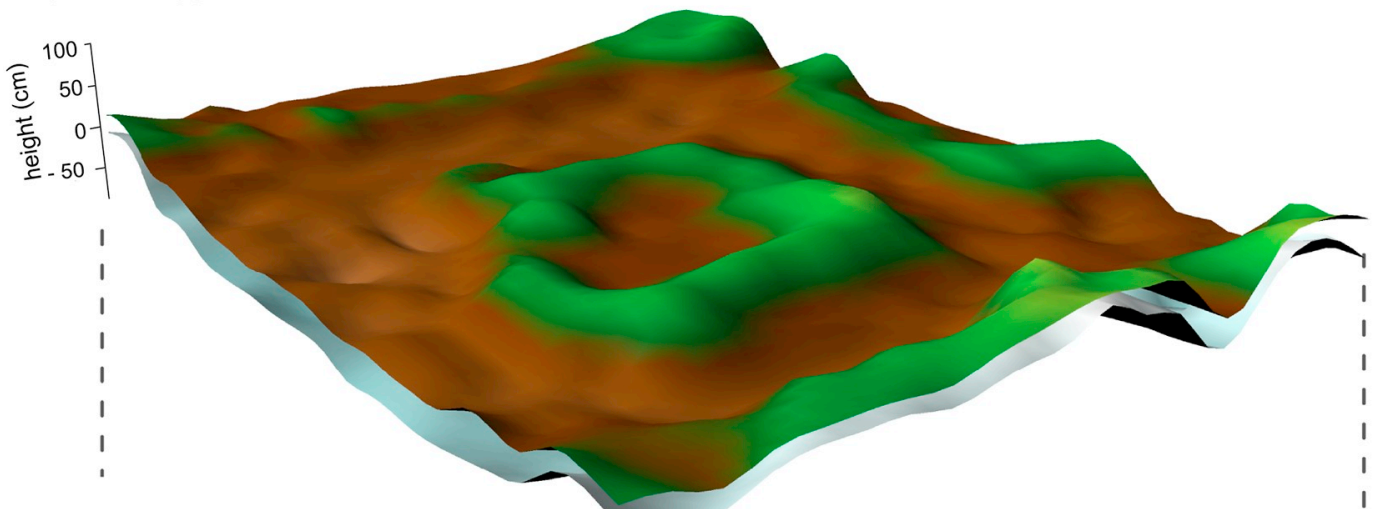

C) Lhc11 polygon - Frost surface elevation

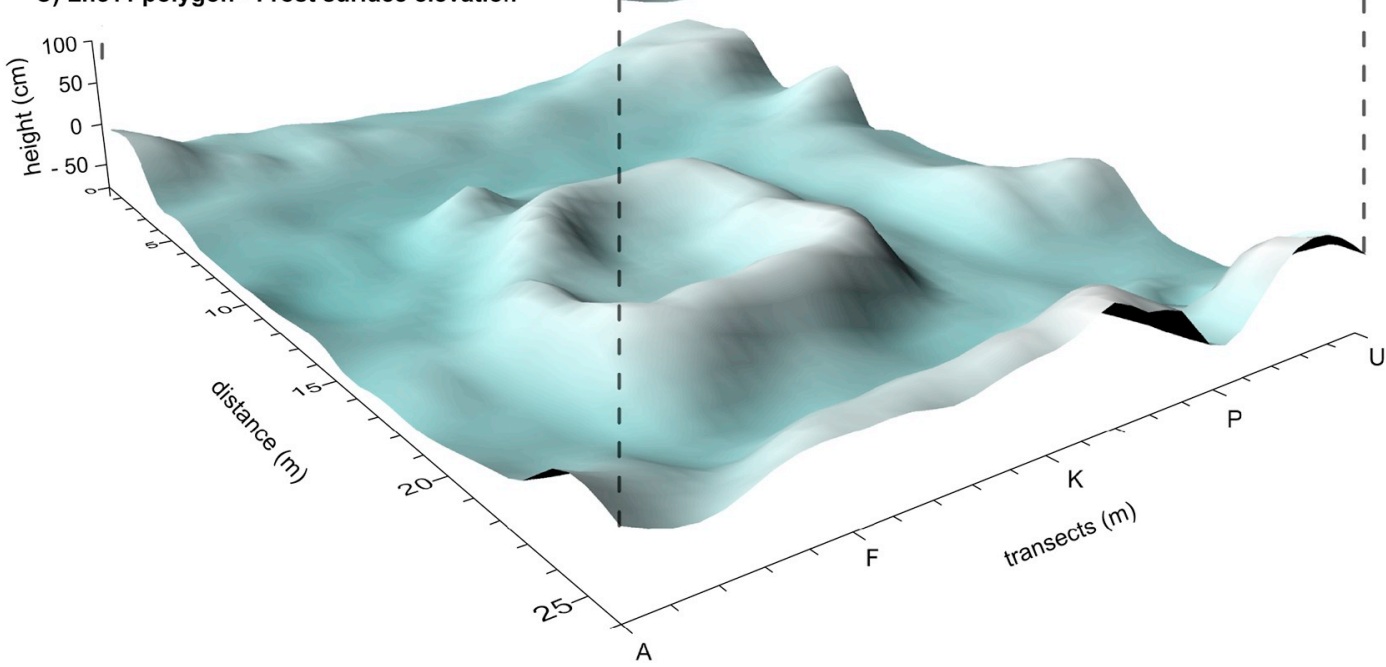

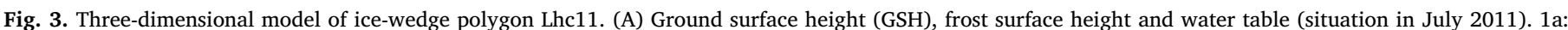

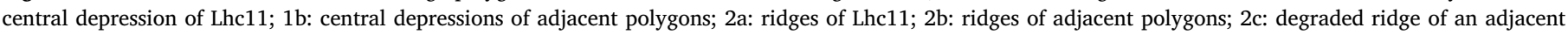

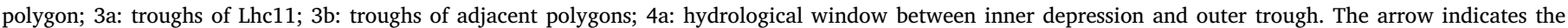
position of peat section j18.80. (B) GSH and (C) frost surface height (situation in July 2011).

ingrown fossils (e.g. roots). We constructed an extensive and a more restricted set of potential fossils to reflect different conditions of preservation and recognisability. Liverworts and lichens were excluded as these only fossilize under very favourable conditions (see Section 4. Discussion). We used only presence/absence data, because of the impossibility to transform vegetation cover into robust and sensible 


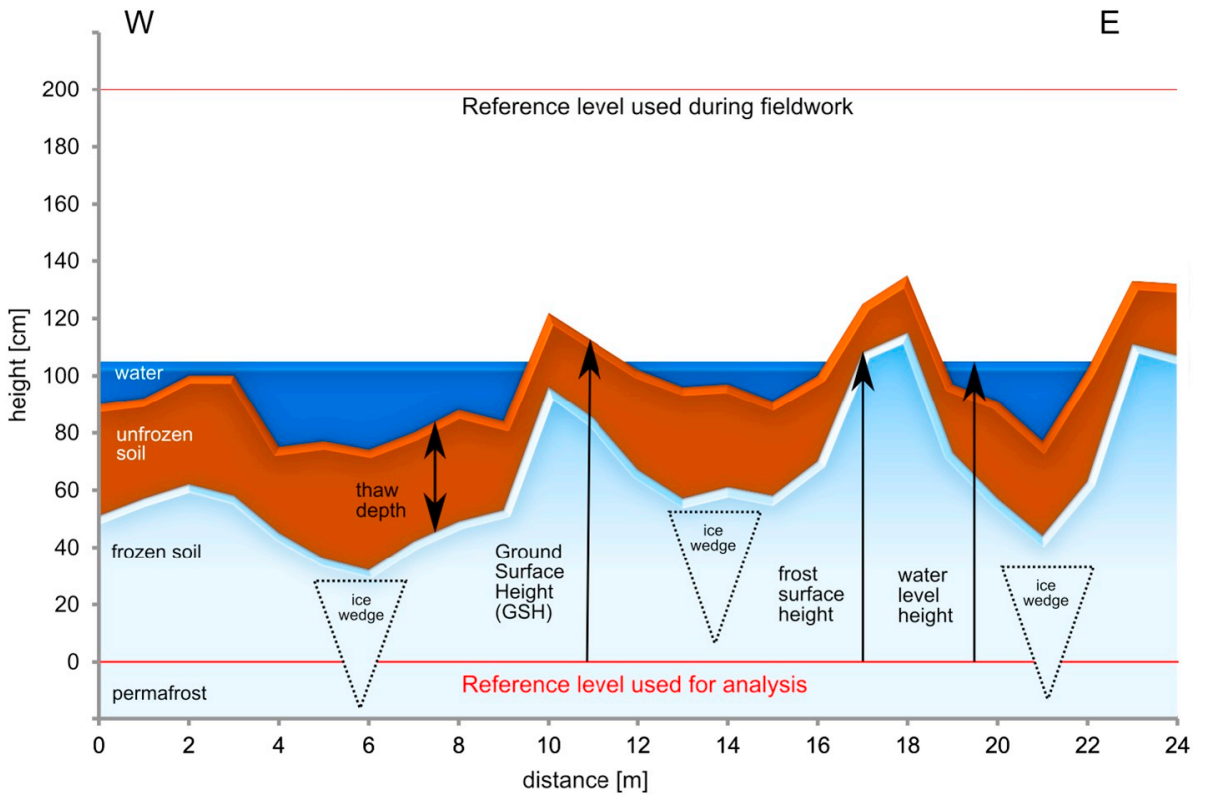

Fig. 4. Cross-section of ice-wedge polygon Lhc11 showing the distribution of frozen soil, unfrozen soil and water along transect $J$ (see Figs. 3 and 6, situation in July 2011). Indicated are the reference level above the study site used during fieldwork, the reference level $200 \mathrm{~cm}$ lower used for analysis, and thaw depth, ground surface height (GSH), frost surface height and water-level height. Location and shape of assumed ice wedges is indicative. macrofossil volume and pollen influx values.

In order to differentiate clearly between determined palynomorph types and inferred plant taxa, the palynomorph types (e.g. BETULA NANA TYPE) are displayed in the text in SMALL CAPITALS and the inferred plant taxa (e.g. Betula exilis) in italics (Joosten and De Klerk, 2002).

To visualize information loss in the process of fossilization we applied Detrended Correspondence Analysis (DCA) using the presence/ absence of (a) modern taxa, (b) 31 potential fossil types and (c) 25 potential fossil types in all 546 plots, using the decorana (DCA) and ordisurf functions (smooth GSH surface plotting) of the package vegan (Oksanen et al., 2016) of the R program (R Core Team, 2013).

\subsection{Development of the GSH models}

To model the relationship between potential fossil assemblages (derived from modern species composition) and ground surface height [GSH] we applied the direct multivariate ordination technique Canonical Correspondence Analysis (CCA; Ter Braak, 1986) using the R package vegan (Oksanen et al., 2016). We calculated two separate CCA models: a 31 types model and a 25 types model, using presence/absence data of the potential fossil types and measured GSH as the only constraining environmental variable. Each model was evaluated with leave-one-out cross validation (Hastie et al., 2009). Quadratic regression was used to assess the relationship between predicted site scores and measured GSH values.

\subsection{GSH modelling of Holocene samples}

The developed GSH models were tested on 52 peat samples from section j18.80 of the same polygon Lhc11 (Fig. 3, Teltewskoi et al., 2016). We used 16 macrofossil and pollen types (1-8 types per sample) for the 31 type model and 14 macrofossil and pollen types (2-10 types per sample) for the 25 type model. Fossil pollen attributable to Poaceae, Betula exilis and Salix were not considered, because these types were present in all peat samples. Outcomes (modelled GSH values in centimetres above reference level) were compared with an expert-based multi-proxy reconstruction of wetness conditions from the same core, which used pollen, non-pollen palynomorphs, macrofossils, testate amoebae, geochemistry and mineral influx data (Teltewskoi et al., 2016). The methodology is summarized in Fig. 5.

\section{Results}

\subsection{Plant communities}

The vegetation of polygon Lhc11 consists of 24 vascular plant, 20 moss and 9 lichen taxa (Table 1 ). Clustering revealed a separation into five communities including three communities (A, B, C) on elevated (drier) sites and two communities (D, E) on lower (wetter) sites (Fig. 6). Forty of the 53 species were characterized as indicator species for these communities. The following communities were distinguished:

(A) The Dicranum acutifolium-Ledum decumbens community $(\mathrm{n}=67)$, on the highest and driest plots on ridges, is dominated by Ledum decumbens, Dicranum acutifolium, Rubus chamaemorus, Betula exilis and Vaccinium vitis-idea and by the lichens Cetraria islandica, Dactylina arctica and Cladonia spp. Vegetation cover (mean cover $100 \%$ ) consists for $20 \%$ of herbs, for $49 \%$ of shrubs, for $21 \%$ of brown mosses, for $4 \%$ of liverworts and for $6 \%$ of lichens. Mean thaw depth is $24 \mathrm{~cm}$.

(B) The Ptilidium ciliare-Ledum decumbens community $(n=40)$, on higher and drier spots on ridges, is dominated by Ledum decumbens, Rubus chamaemorus, Ptilidium ciliare, Betula exilis, Vaccinium vitisidea, Aulacomnium palustre and Orthocaulus binsteadii and by lichen species. Vegetation cover (mean cover 97\%) consists for $18 \%$ of herbs, for $38 \%$ of shrubs, for $13 \%$ of brown mosses, for $6 \%$ of Sphagnum, for $20 \%$ of liverworts and for $5 \%$ of lichens. Mean open water cover is $3 \%$, mean thaw depth $22 \mathrm{~cm}$.

(C) The Hylocomium splendens-Ledum decumbens community $(\mathrm{n}=87)$, distributed from low dry plots on ridges along transitional plots to shallow wet plots, is dominated by Ledum decumbens, Betula exilis, Rubus chamaemorus, Vaccinium vitis-idea and Sphagnum squarrosum. Vegetation cover (mean cover $85 \%$ ) consists for $25 \%$ of herbs, for $55 \%$ of shrubs, for $7 \%$ of brown mosses, for $9 \%$ of Sphagnum, for $2 \%$ of liverworts and for $2 \%$ of lichens. Mean open water cover is $15 \%$, mean thaw depth $32 \mathrm{~cm}$.

(D) The Sphagnum squarrosum-Carex aquatilis community $(\mathrm{n}=127)$, predominately found at degrading ridges and at shallow wet plots, is dominated by Sphagnum squarrosum, Sphagnum flexuosum, Carex aquatilis, Salix spp. and Betula exilis. Vegetation cover (mean cover $65 \%$ ) consists for $18 \%$ of herbs, for $32 \%$ of shrubs, for $4 \%$ of brown mosses, for $45 \%$ of Sphagnum and for $1 \%$ of liverworts. Mean open water cover is $35 \%$, mean thaw depth $37 \mathrm{~cm}$. 


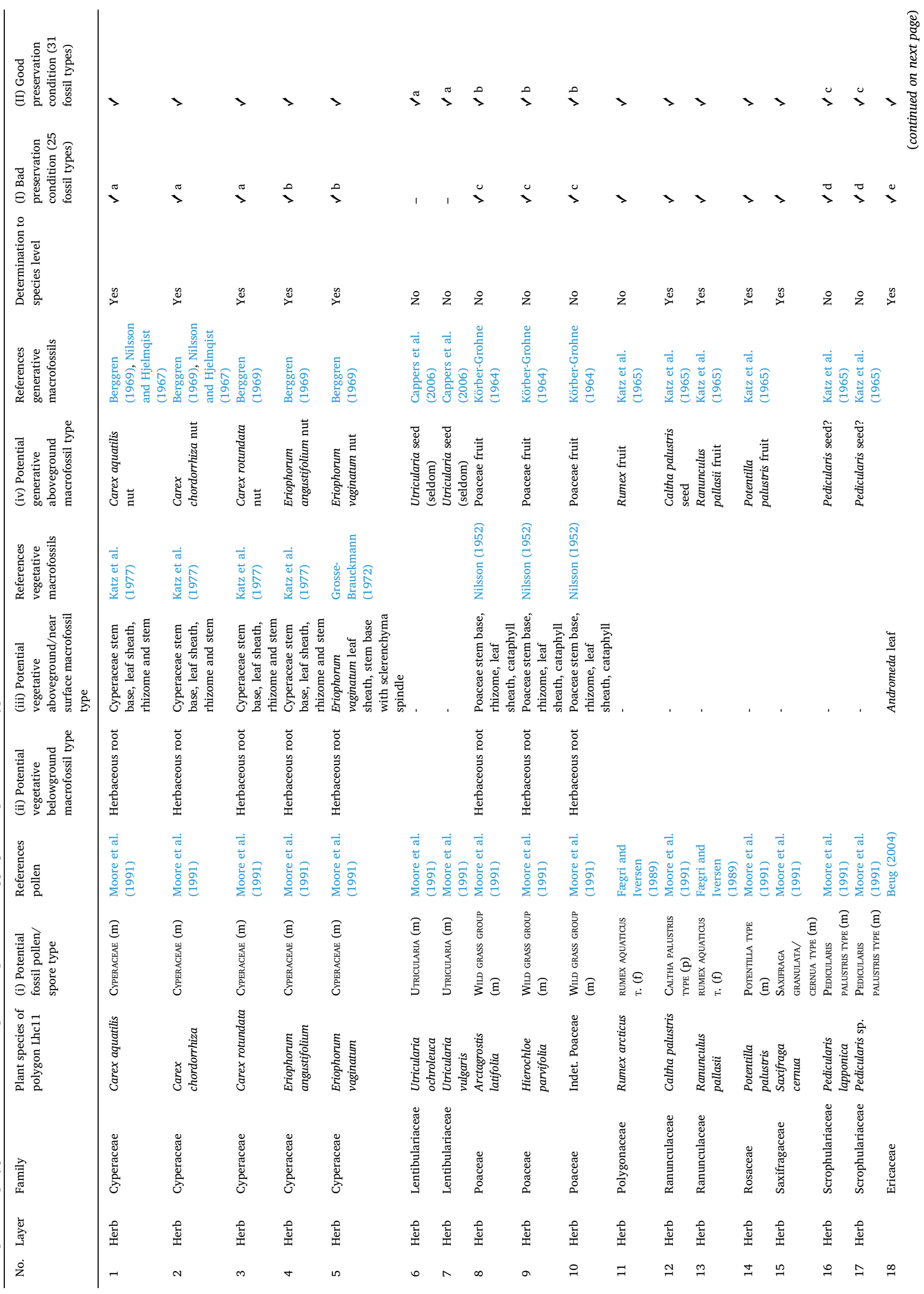




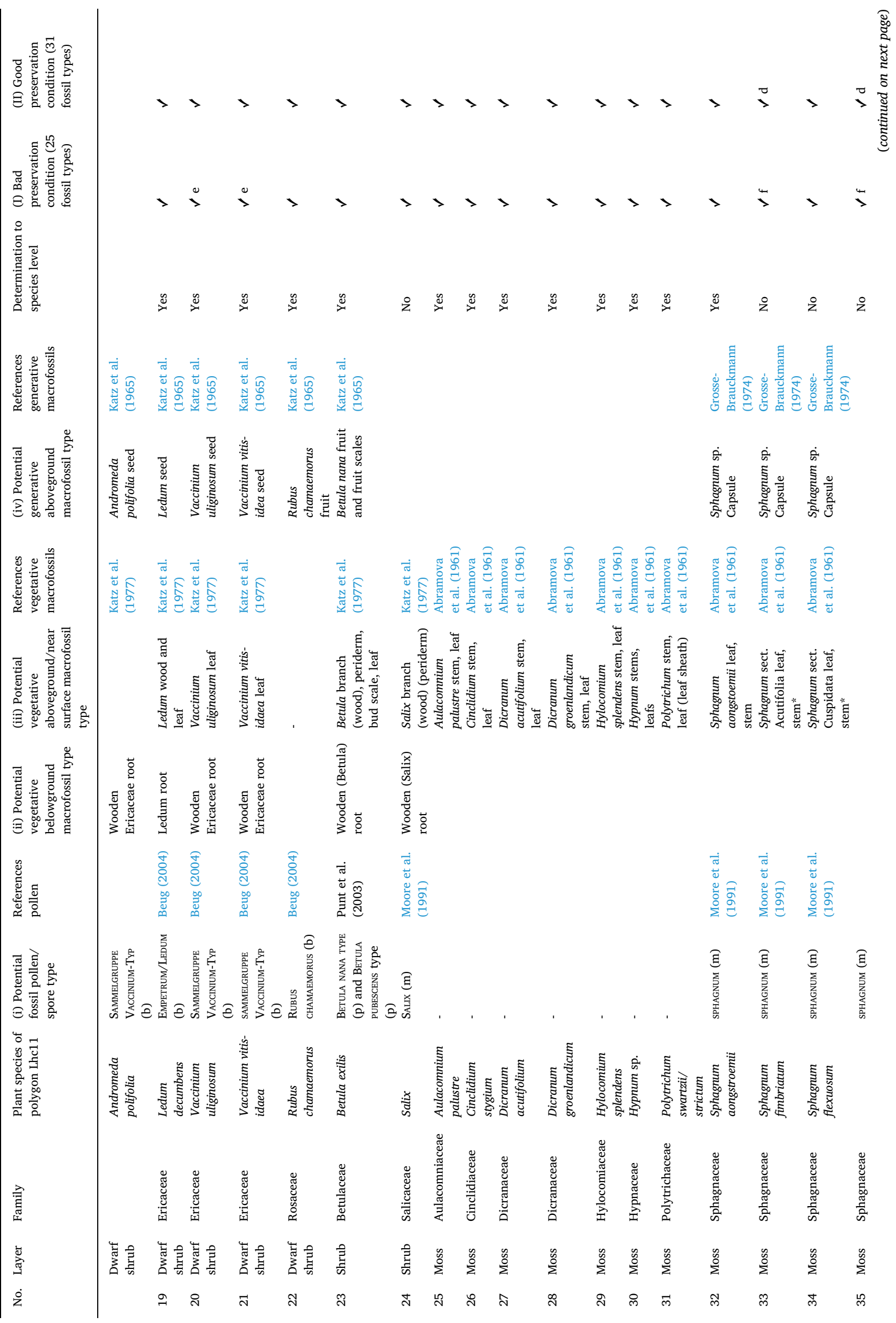




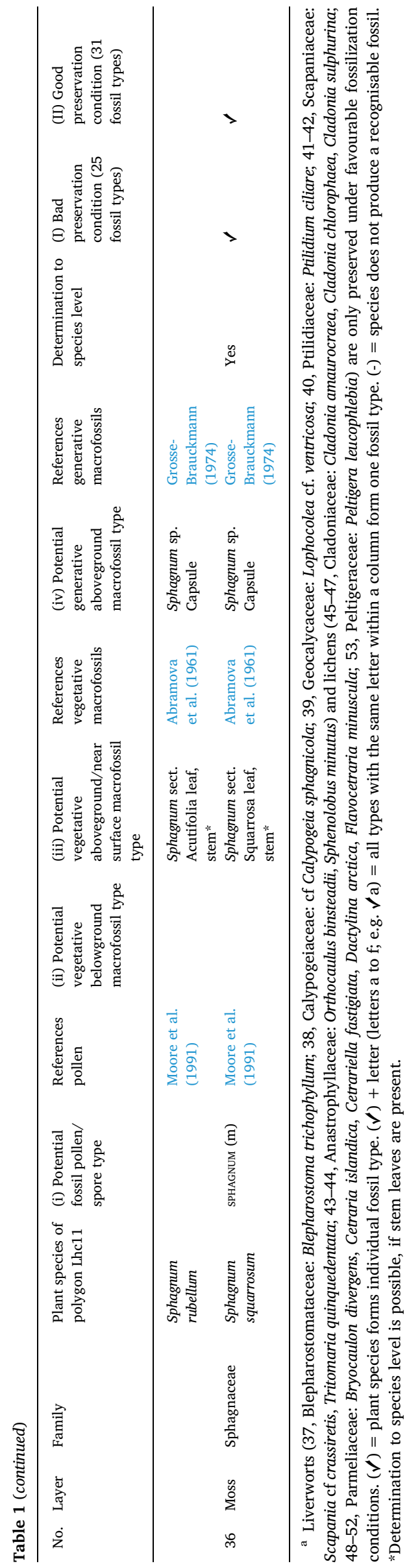

(E) The Utricularia ochroleuca-Carex aquatilis community $(n=225)$, on wet plots in troughs and in central depressions, is dominated by Sphagnum flexuosum, Carex aquatilis, Eriophorum angustifolium, Utricularia vulgaris, Utricularia ochroleuca and Potentilla palustris. Vegetation cover (mean cover $24 \%$ ) consists for $37 \%$ of herbs, for $5 \%$ of shrubs and for $58 \%$ of Sphagnum. Mean open water cover is $76 \%$, mean thaw depth $38 \mathrm{~cm}$.

\subsection{Vegetation, GSH, frost surface height and thaw depth}

The five plant communities show a clear differentiation with respect to ground surface height, frost surface height and total vegetation cover (Figs. 7,8 ) with a slight overlap between Ptilidium ciliare-Ledum decumbens and Hylocomium splendens-Ledum decumbens communities.

GSH (total range $110 \mathrm{~cm}$ ) from the driest to the wettest community is on average 132, 118, 109, 98 and $82 \mathrm{~cm}$, frost surface height (total range $121 \mathrm{~cm}$ ) 108, 95, 77, 61 and $44 \mathrm{~cm}$ above reference, respectively. Average thaw depth over all communities is $34 \mathrm{~cm}$, with a variation from 7 to $89 \mathrm{~cm}$ (Fig. 8).

\subsection{Potential fossil types}

The 36 encountered plant species provided a maximum of 31 fossil types, whereas exclusion of the two Utricularia species (which hardly produce fossils) and conglomeration of eight species (which are hard to distinguish) to three fossil types (Carex aquatilis $+C$. chordorrhiza $+C$. rotundata, Eriophorum angustifolium $+E$. vaginatum, and Andromeda polifolia + Vaccinium uliginosum + Vaccinium vitis-idea) provided 25 fossil types (Table 1).

All three data sets (modern vegetation, 31 fossil types and 25 fossil types selection) are clearly arranged along DCA axis 1 describing a wetness gradient (Fig. 9). Modern vegetation shows the widest plot distribution along DCA axis 1 . The 31 fossil types have a similar distribution with slightly shorter gradient length, whereas the 25 fossil types are located within the range of 31 fossil types and have the shortest gradient length with a distinctly shorter gradient extension on the right side (wetter conditions).

\subsection{GSH models}

The two models were evaluated by comparing estimated site scores and measured ground surface heights of each plot. The CCA site scores of axis 1 explain 79.6\% (31 types model) and 76.1\% (25 types model) of the variation in measured GSH (Fig. 10A). A linear relationship exists between measured and modelled GSH (Fig. 10B). Modelled GSH values range from 75 to $137 \mathrm{~cm}$ (31 types model) and from 79 to $139 \mathrm{~cm}(25$ types model) whereas measured GSH values range from 47 to $157 \mathrm{~cm}$. The Root Mean Square Error (RMSE) is $9.0 \mathrm{~cm}$ (31 types model) and $9.7 \mathrm{~cm}$ (25 types model).

\subsection{GSH modelling of Holocene samples}

For peat section $\mathrm{j} 18.80$ the modelled ground surface height shows similar trends for the 31 and the 25 types model (Fig. 11). In both cases modelled GSH is low from the bottom at $105 \mathrm{~cm}$ depth to about $20 \mathrm{~cm}$ depth of the section. GSH ranges between $80-110 \mathrm{~cm}$ (31 types model) and $80-105 \mathrm{~cm}$ (25 types model) above reference level. From $20 \mathrm{~cm}$ depth to the top of the section modelled GSH ranges between $105-135 \mathrm{~cm}$ (31 types model) and 105-125 cm (25 types model). For these upper $20 \mathrm{~cm}$ both models indicate a clear trend to higher GSH, with lower GSHs (wetter conditions) at about $10 \mathrm{~cm}$ section depth. In the lower part of the section (105-20 cm depth) the 31 types model produces three noticeable peaks with higher GSH (drier conditions) at 88-86, 64 and $48 \mathrm{~cm}$ depth.

The wet phase from 30 until $20 \mathrm{~cm}$ depth reconstructed by Teltewskoi et al. (2016) is paralleled by a clear wetter trend in the 31 
A)

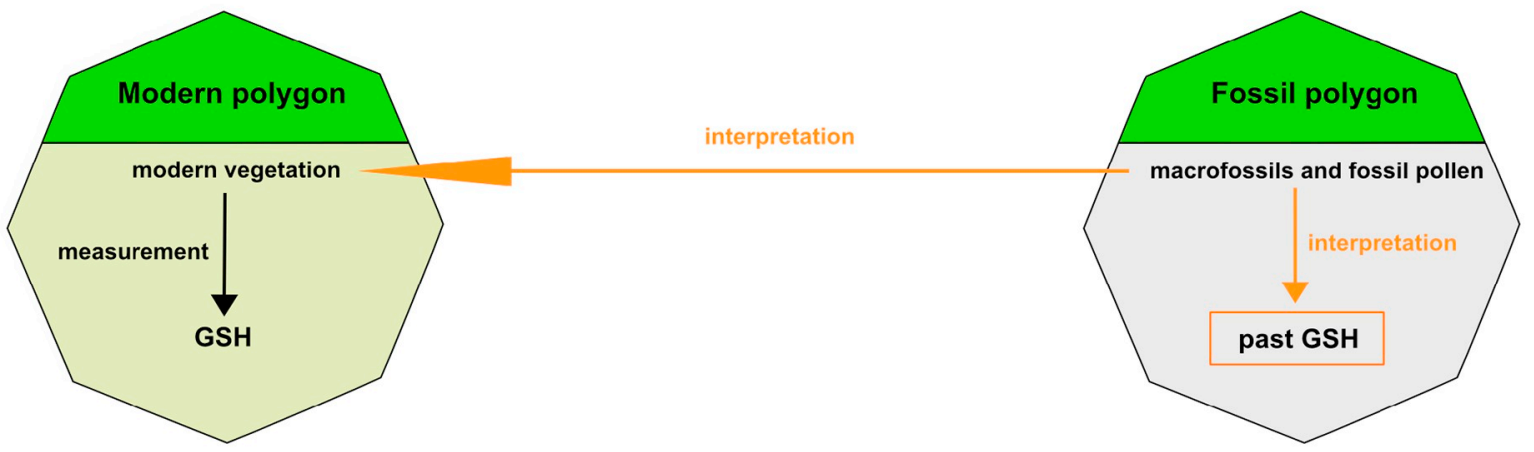

B)

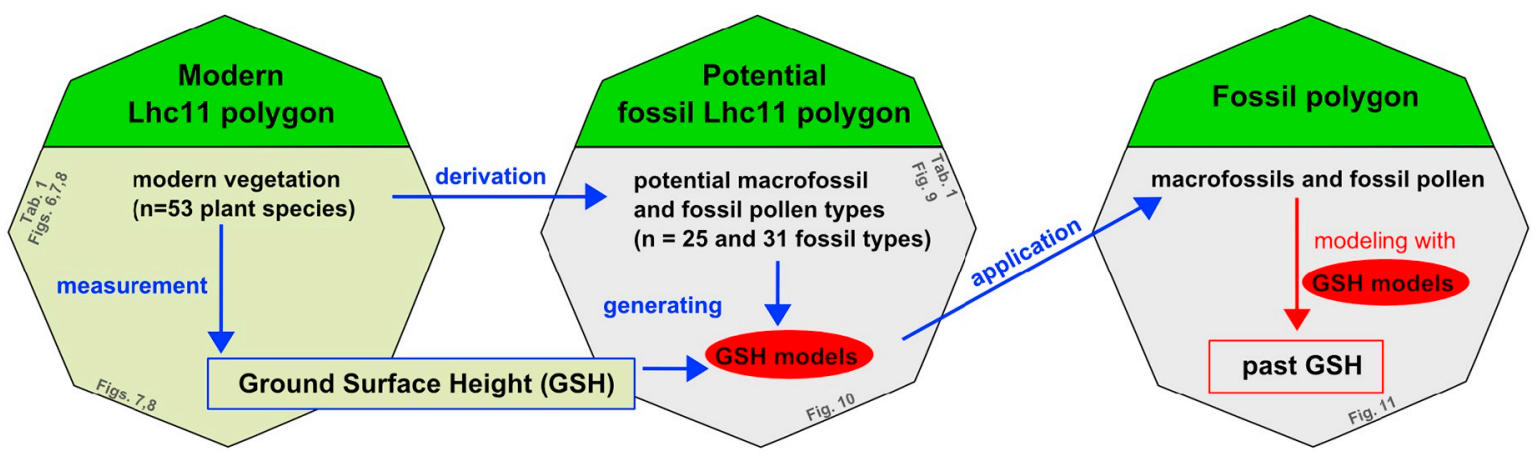

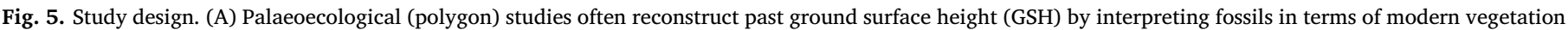

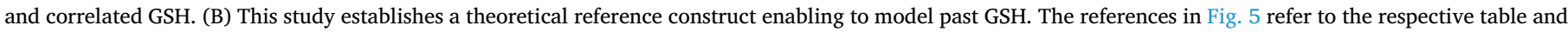
figures in this paper.

and 25 types models (Fig. 11), whereas the dry/wet phase reconstructed around $10 \mathrm{~cm}$ depth is paralleled by a wetness-indicating peak in the 25 types model and a longer wetter phase in the 31 types model.

\section{Discussion}

\subsection{Modern vegetation, GSH, frost surface height and thaw depth}

The clear differentiation of the five plant communities in terms of GSH, frost surface height, litter and vegetation cover (Figs. 6, 7, 8), and the high number of significant indicator species confirm the pattern already identified in other studies of Arctic ice-wedge polygons (De Klerk et al., 2009, 2014; Minke et al., 2007, 2009; Boike et al., 2013; Zibulski et al., 2013, 2016; Wolter et al., 2016). The applied relevé size of $1 \mathrm{~m}^{2}$ corresponds to the recommended sampling size for peatlands of 1-5 $\mathrm{m}^{2}$ (Glavac, 1996; Westhoff and Van der Maarel, 1973). However, due to contiguous sampling and small-scale site heterogeneity our relevés may represent a mixture of vegetation types. As a consequence, unusual combinations occur, e.g. some shrubs in the Utricularia ochroleuca-Carex aquatilis community, leading to a reduced indicative 'sharpness' of the single samples and elaborated communities.

In terms of GSH, frost surface height and vegetation cover, the central Ptilidium ciliare-Ledum decumbens-, Hylocomium splendens-Ledum decumbens- and Sphagnum squarrosum-Carex aquatilis communities show conspicuous overlap (Figs. 7, 8). These communities are subject to large water-level fluctuations typical for permafrost environments, where permafrost restricts downward discharge and runoff responds quickly to snowmelt and rainfall (French, 2007). Furthermore, the small-sized water bodies in polygonal peatlands collect runoff from adjacent ridges and have higher rates of evapotranspiration compared to lakes, leading to strong water-level fluctuations. During fieldwork in July and August 2011, the water level in our study site oscillated $16 \mathrm{~cm}$ (the same fluctuations were measured in a polygonal pond on $100 \mathrm{~m}$ distance from our site by Schneider et al., 2016), affecting mainly the Hylocomium splendens-Ledum decumbens- and Sphagnum squarrosum-Carex aquatilis communities, which occupy an intermediate wetness position (Fig. 7). In our study the most explicit 'transitional' vegetation is the Hylocomium splendens-Ledum decumbens community, which is characterized by the largest ranges in GSH, frost surface height and thaw depth. The Dicranum acutifolium-Ledum decumbens- and Utricularia ochroleuca-Carex aquatilis communities, representing the extreme ends of the wetness gradient, are well differentiated against the other communities (Figs. 7,8 ). They are located on dry ridges and deep wet troughs/depressions, respectively, meaning that even strong external influences like drought or spring snow melt will not strongly change the respective site conditions.

In contrast to a Canadian polygonal landscape (Becker and Pollard, 2016), the wettest community of polygon Lhc11 has less plant species than the driest community. This difference is probably caused by the more explicit microtopography of the old polygon Lhc11, which prevents the exchange of mesic and wet species. This corresponds with the increased plant species diversity on better drained tundra slope sites (Sitte et al., 2002) and results in more floristic similarities between ridge and transition than between transition and depression/through in Siberian ice-wedge polygons (Zibulski et al., 2016).

In terms of thaw depth the plant communities of Lhc11 show less differentiation (Fig. 8). Small-scale variety in thaw depth is controlled by topography, soil moisture (Nelson et al., 1998) and local vegetationhydrogeomorphic factors (Minke et al., 2009; Gangodagamage et al., 2014). On the exposed high and dry ridges of Lhc11, thaw depth is shallow, because in winter the thin snow cover enables deep soilfreezing (Blok et al., 2010), whereas in summer the dwarf shrubs give shade (Nauta et al., 2015), the dry mosses, litter and surficial peat provide insulation (Gornall et al., 2007; O'Donnell et al., 2009) and the light coloured lichens increase the albedo (Longton, 1988). Depressions and troughs thaw deeper, because in winter the thick snow cover insulates against cold winter air temperatures (Blok et al., 2010) whereas in summer the collecting meltwater, the low albedo of the water, and the poorly shading and insulating vegetation and litter support a downward heat transfer (Schultz, 1995). 


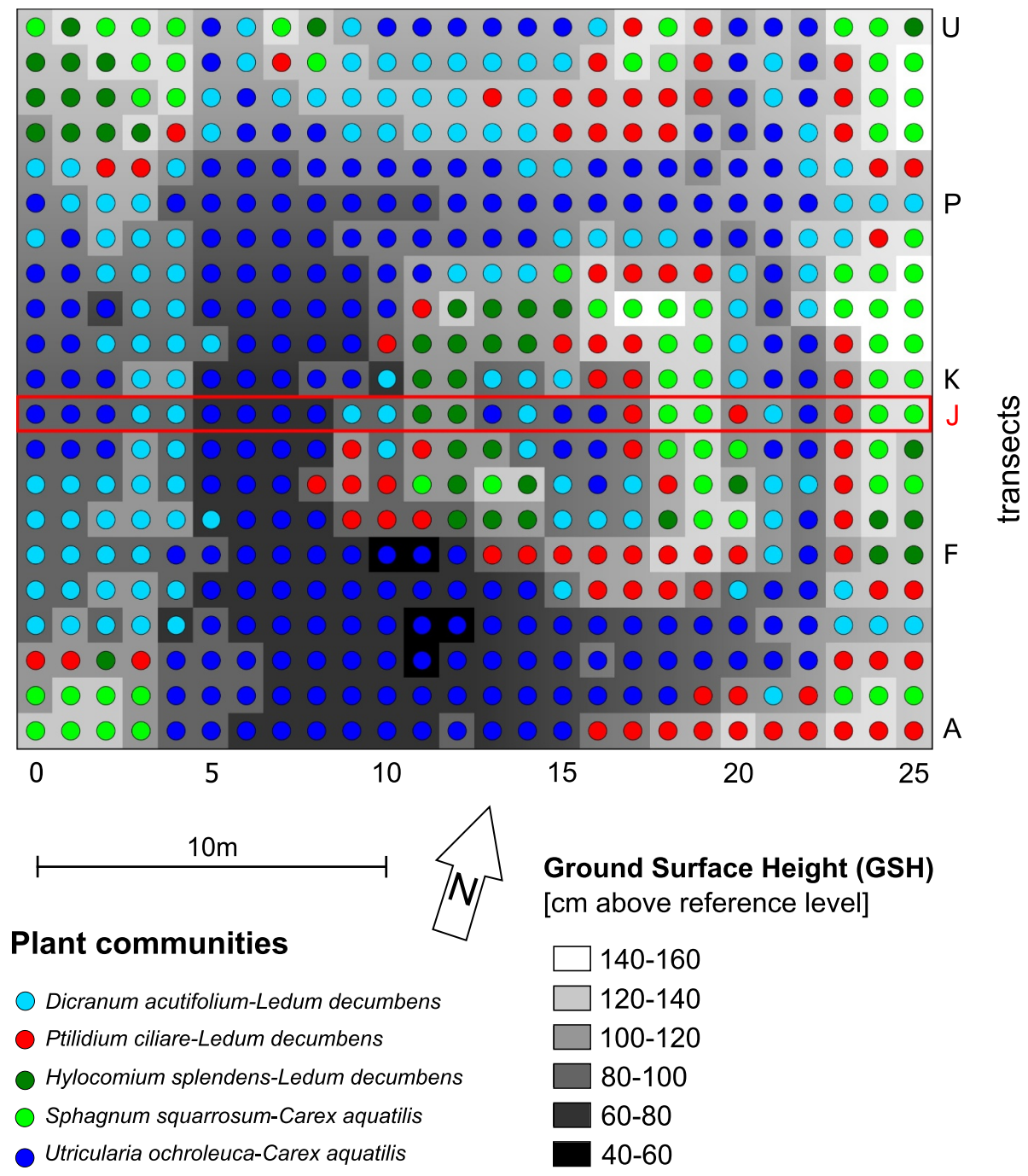

Fig. 6. Distribution of the five plant communities within polygon Lhc11 in relation to ground surface height ( $\mathrm{n}=546$; data from July 2011$)$.

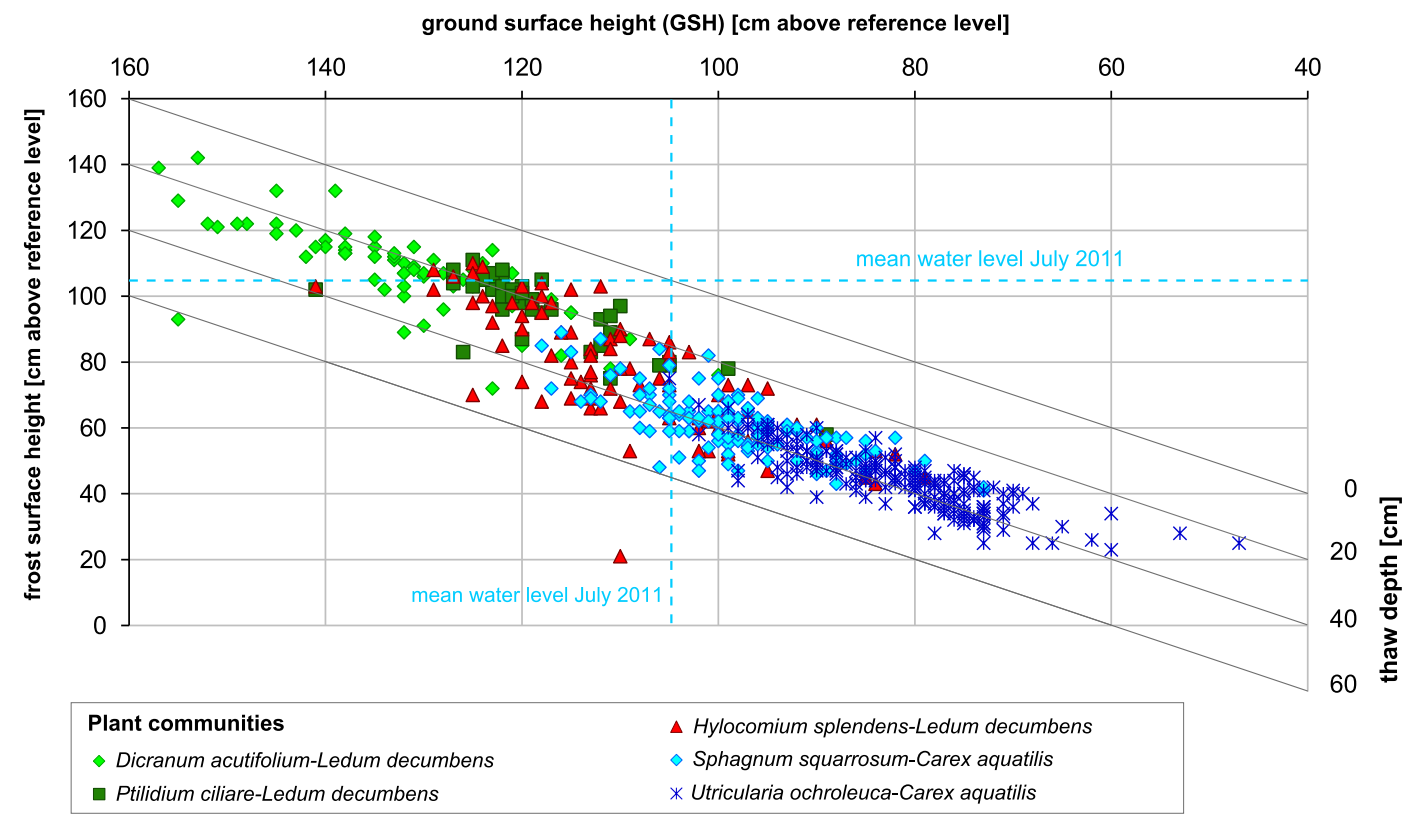

Fig. 7. Distribution of the five plant communities of polygon Lhc11 in relation to ground surface height, frost surface height and thaw depth ( $\mathrm{n}=546$; data from July 2011). 

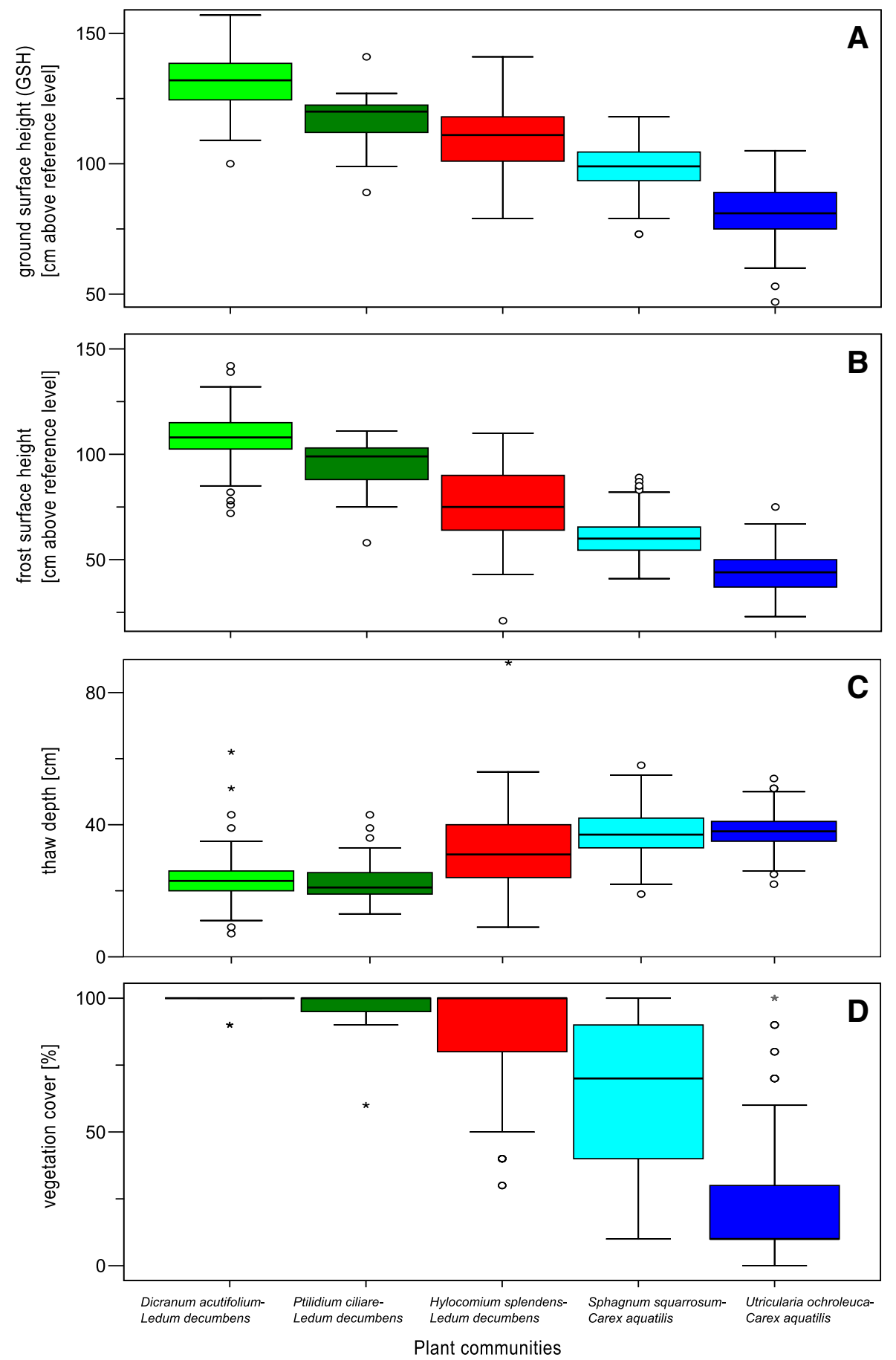

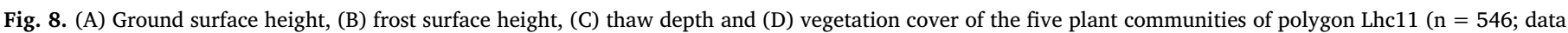

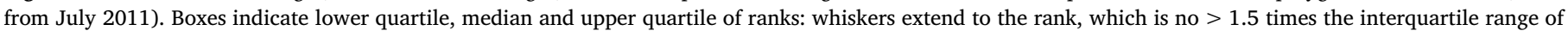
the box.

\subsection{Potential fossil types}

The applied combination of macrofossil and pollen analysis is well established in palaeoecology (cf. Aaby, 1986). Whereas pollen with its generally wider distribution is typically used to reconstruct regional, landscape-scale vegetation development, plant macrofossils are generally deposited very close to the producing plants and therefore best suited to reconstruct local (on-site) conditions. In Arctic polygon mires, however, the extralocal signal (sensu Janssen, 1966) of pollen and other microfossils is - because of the low height of the vegetation - very weak or even absent (De Klerk et al., 2009, 2014), which allows microfossils also to be used for local inference. Regional pollen deposition in the Arctic is comparatively low and - per definition - equally distributed over the polygon, which facilitates this component to be singled out in a quantitative approach. In a qualitative approach (presence-absence) as applied by us, regional pollen deposition of also locally occurring polygon mire plant species will somewhat obscure the interpretation of pollen data in terms of local relief differences. This effect can be addressed by removing all pollen types with a possible regional distribution from the data set, as we have done for pollen attributable to Poaceae, Salix and Betula exilis. Although earlier studies showed a higher wetness-reconstruction potential for macro- compared to 


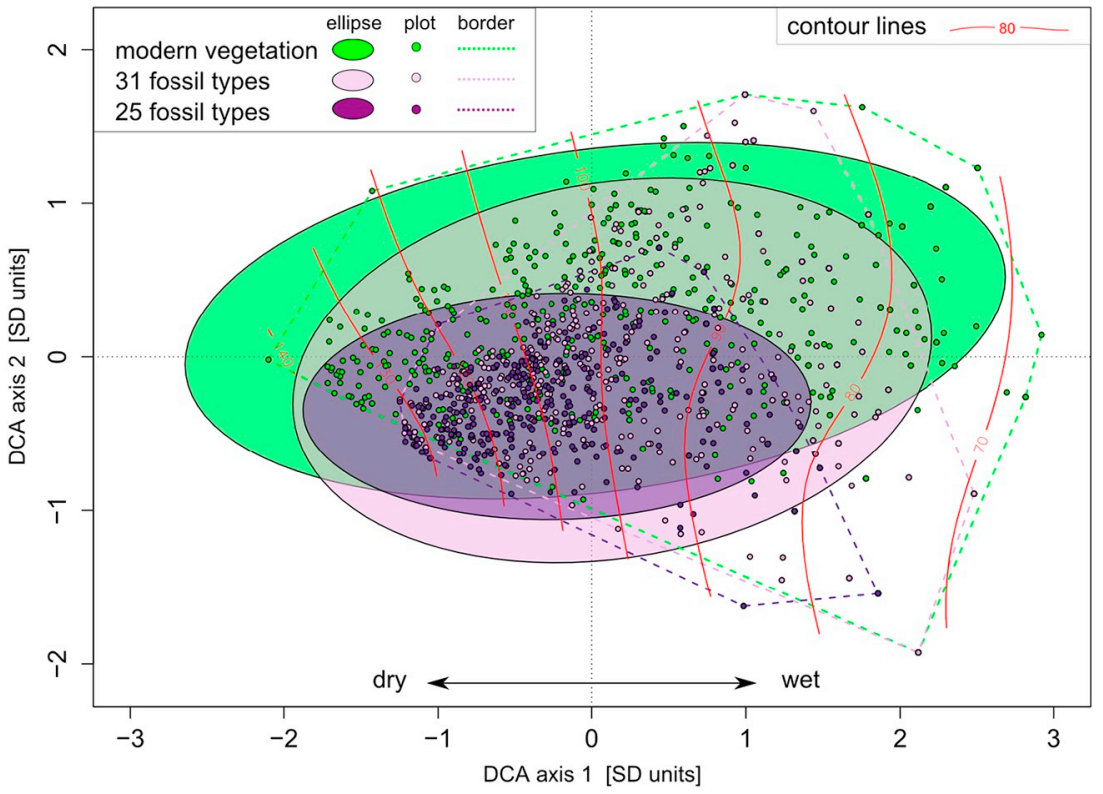

Fig. 9. DCA ordination diagram for comparing plot similarities with respect to (i) modern species, (ii) 31 potential fossil types and (iii) 25 potential fossil types in the 546 plots of polygon Lhc11. Each subset is summarized by an ellipse describing standard deviations of points with a confidence limit of 0.95. Eigenvalues: axis $1-0.469$, axis $2-0.255$; gradient lengths: axis $1-5.021$, axis $2-3.635$. microfossils (Teltewskoi et al., 2016), the combined use of two (or more) types of proxies (cf. Blundell and Barber, 2005; Magyari et al., 2009) provides an even finer reconstruction, because of finer taxonomic resolution.

In general, peat- and brown mosses, belowground herb and shrub parts and fruits and seeds have a good fossilization potential in peatlands (Grosse-Brauckmann, 1972, 1974), whereas the macrofossil incidence of lichens and especially liverworts is low (Birks, 2001), except under very favourable conditions (incl. permafrost) (for lichens see Sernander, 1918; Kuc, 1974; Tolonen, 1971; Foster, 1984; Tolonen et al., 1985; Van der Knaap et al., 1989; Zimmermann and Lavoie, 2001; Bauer and Vitt, 2011; for liverworts Klinger, 1986; Teltewskoi et al., 2016).

Carex and Eriophorum species as potentially important indicators for wetness conditions produce only one determinable pollen type (CYPERACEAE (m)) and poorly differentiable vegetative macrofossils. Determination up to species level is often only possible with nuts, which may be produced abundantly but may also be transported by water or wind (extra-local input). The herb Utricularia frequently grows in wet polygon troughs and is a good indicator for wet habitats, but produces little or no pollen (De Klerk et al., 2014; Beretta et al., 2014; in 2011 we did not find any flowering specimen), consequently also hardly seeds, whereas its herbaceous, nutrient-rich tissue is subject to rapid decomposition. In contrast, the dwarf shrubs and shrubs Andromeda polifolia, Ledum decumbens, Vaccinium uliginosum, V. vitis-idaea, Rubus chamaemorus, Betula exilis and Salix are typical for transitional dry/wet and dry habitats and often leave macrofossils (wood, periderm, leaves, fruits, seeds) whereas these taxa can also - to some extent - be differentiated by their pollen (Table 1).

We use the category "Potential vegetative aboveground/near surface macrofossil type", to accommodate for vegetative plant parts that are difficult to assign to above- or belowground, especially the shrubs and dwarf shrubs Andromeda polifolia, Ledum decumbens, Vaccinium uliginosum, Vaccinium vitis-idaea, Rubus chamaemorus, Betula exilis and Salix with repent growth along the soil surface (Table 1).

Brown mosses, which at the study site mainly indicate low dry ridges and dry/wet transitional habitats, and peat mosses (Sphagnum), which dominate shallow wet and dry/wet transition sites (De Klerk et al., 2014), are favourable for macrofossil analysis but cannot (yet) be differentiated by their spores (cf. Boros and Járai-Komlódi, 1975; Tallis, 1962). Fossils from Poaceae mainly indicate dry conditions, but may also be derived from the wet growing Arctagrostis latifolia (which grows rarely in polygon Lhc11).

Despite these shortcomings, the potential macrofossil and pollen
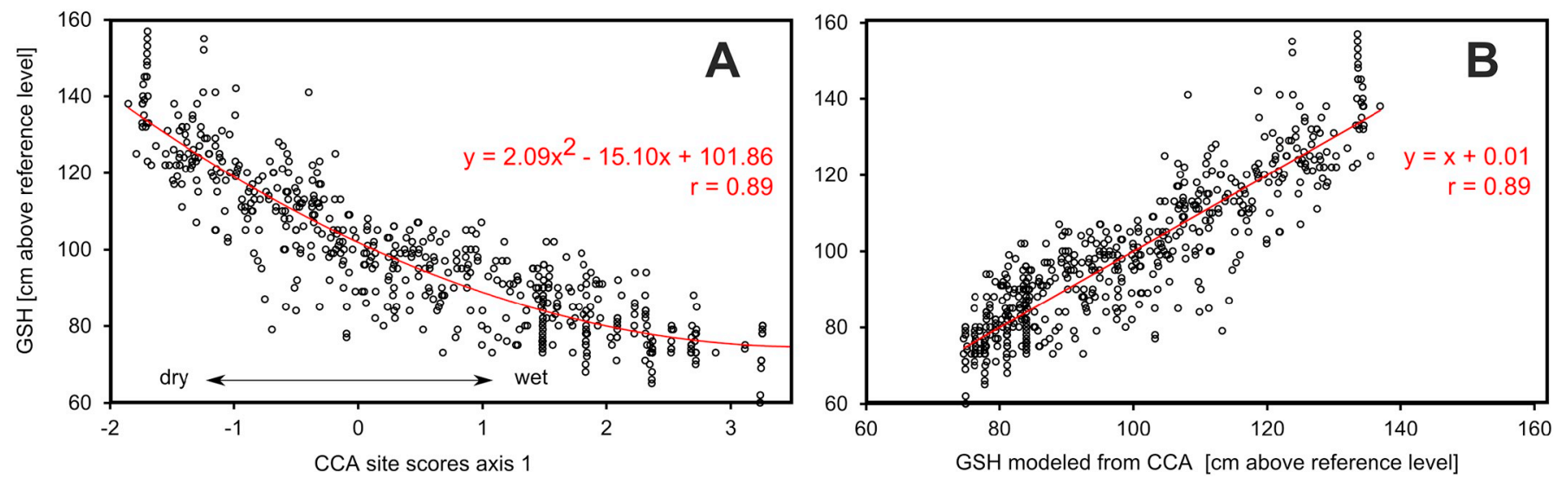

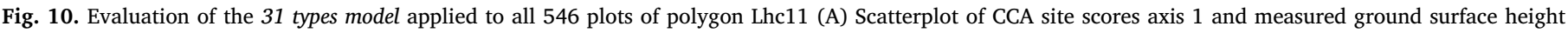

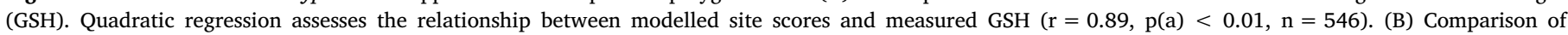

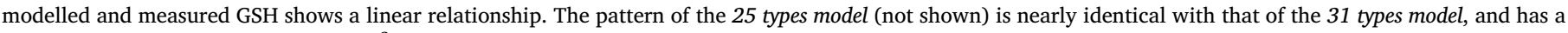
similar quadratic regression $\left(y=2.78 x^{2}-14.38 x+102.64\right)$, but a slightly lower correlation coefficient $(r=0.87, p(a)<0.01, n=546)$. 
m
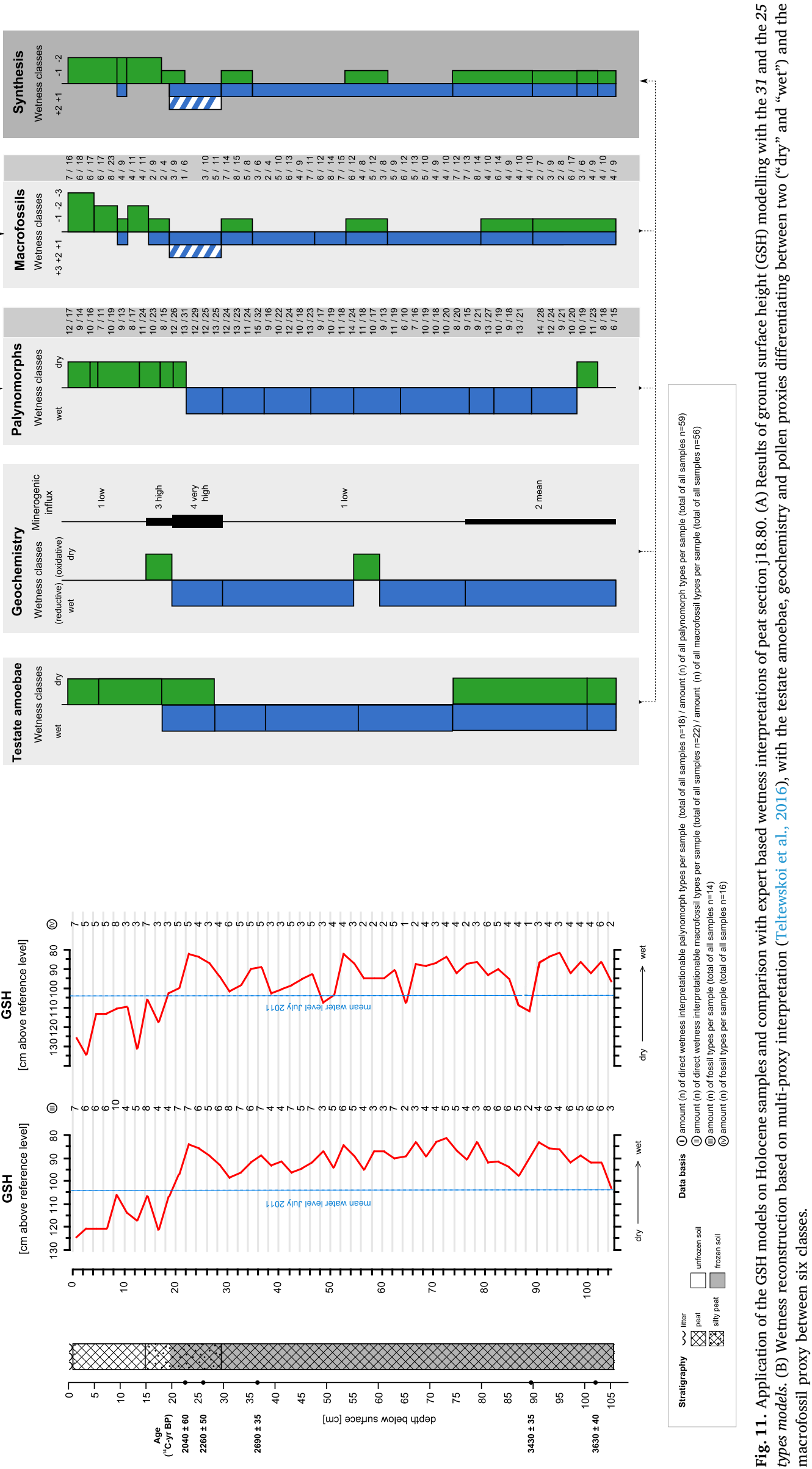

].
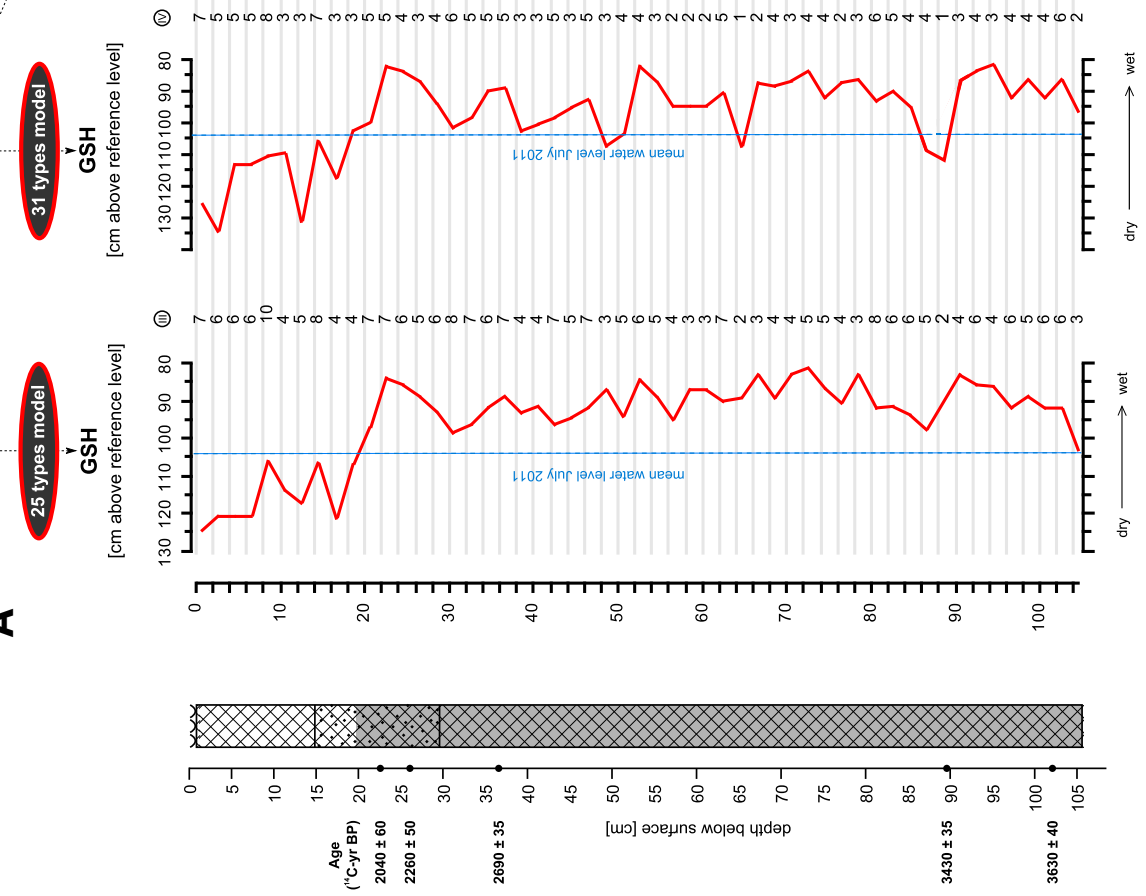
types allow a clear differentiation of different polygonal microsites.

\subsection{GSH models}

Our study is based on the assumption that the investigated icewedge polygon systems developed under similar conditions and that ecological niches of species are conservative over the timescale of polygon mire development, which allows the present to be used as a reference for the past (uniformitarianism; Birks and Birks, 1980; Fig. 5A). In our case this assumption may be valid as no changes in the plant species spectrum have occurred (which could have modified the ecological niches by changing competition, cf. Kotowski et al., 1998; Koska et al., 2001) and no (meaningful) evolutionary processes will have occurred over the short available time (a few thousand years).

To develop models for community-environment relationships CCA is a common method (Leyer and Wesche, 2007). Our CCA based GSH models with $\mathrm{R}^{2}>0.7$ indicate strong correlations (Leyer and Wesche, 2007) and a close relationship between the assemblages of potential fossil types and measured ground surface height. With RMSE values below $10 \mathrm{~cm}$ (i.e. $<20 \%$ of the modelled GSH range), both GSH models show high accuracy in prediction.

Probably plant fossil based GSH models for polygon mires reach their limit with RMSE $<10 \mathrm{~cm}$ because of natural water-level fluctuations and the accompanied mixture of plant species, plus the centimetre-scale size of several macrofossil remains determining reconstruction resolution.

The vegetation-water table transfer function of Väliranta et al. $(2007,2012)$ has a higher model accuracy $\left(r^{2}=0.95\right.$, RMSE $\left.2.9 \mathrm{~cm}\right)$, probably conditioned by the use of a relatively small modern vegetation data set with a distinct water-table gradient, and the use of plant species coverages instead of presence-absence data.

\subsection{GSH modelling of Holocene samples}

The modelled ground surface height values of peat section $\mathrm{j} 18.80$ show a similar pattern compared to the expert multi-proxy based reconstruction of wetness conditions of Teltewskoi et al. (2016) (Fig. 11). This correspondence shows the robustness of the modelling approach, as the majority of encountered fossil types in the peat section (75 out of 115 types) could not be considered, because of absence in the calibration set, in which furthermore only absence/presence data had been used. The wider GSH range and stronger peaks of the 31 types model compared to the 25 types model are attributable to the inclusion of more potential fossil types of taxa with distinct wetness requirements (Carex aquatilis, Eriophorum angustifolium: deep wet; C. chordorrhiza, C. rotundata: shallow wet; E. vaginatum, Andromeda polifolia: dry/wet; Vaccinium uliginosum: dry and $V$. vitis-idaea: very dry). However, if the fossils of these species cannot be distinguished to species level, this information could not be used to reconstruct GSH with the 31 types model. Consequently, the number of macrofossils and pollen types used in the 31 types model is in various palaeoecological samples lower than in the 25 types model, because the former does not contain lumped types.

Fossil pollen types occurring in all peat samples (i.e. those attributable to Poaceae, Betula and Salix) do not differentiate for local site conditions in this merely qualitative method. These types belong to plant taxa present in the polygon and with good extralocal pollen dispersal, or to types with a good regional dispersal. For these taxa only macrofossils may indicate local vegetation changes over time.

The peak in $88.5 \mathrm{~cm}$ depth is based on Betula macrofossil remains (Fig. 11, Teltewskoi et al., 2016), which might lead to an overestimation of dryness. Similarly, the peak in $64.5 \mathrm{~cm}$ depth is only based on the occurrence of RUMEX AQUATICUS T. pollen, which occurs in most samples from 105 till $20 \mathrm{~cm}$ section depth and thus rather reflects a regional than a local signal. Only one Rumex plant was observed at a wet plot in our study site, but the corresponding plot centre was higher than where the plant was actually growing. Consequently in our analysis Rumex was assigned to drier conditions than in reality prevailed. Since RumeX AQuATicus T. pollen shows a wide dispersal (De Klerk et al., 2014), the type should be excluded from further modelling studies; which would not necessarily impair interpretational quality (cf. Waller et al., 2017).

Despite these shortcomings, including the limitations of the calibration set (one data set from only one study site and correlation of plant species with plot centre not with actual position), the GSH models show robust results.

\section{Conclusions}

GSH models for reconstructing polygonal microtopography based on measured GSH and potential plant fossil types derived from modern vegetation lead to similar results as expert based interpretations of macro- and microfossil assemblages, but with less effort. The presented methodical approach can be applied, evaluated and possibly extended at other polygon mire sites. Such GSH models facilitate quantitative, objective GSH detection and comparison between polygonal sites in terms of palaeo-microtopography and associated greenhouse gas fluxes, which will increase our understanding of polygon development and the reaction of polygon mires on climate change.

\section{Acknowledgments}

This paper is a contribution to the project "Polygons in tundra wetlands: state and dynamics under climate variability in polar regions (POLYGON)" financed by the Deutsche Forschungsgemeinschaft (DFG) by DFG-grants Jo 332-14-1, He3622/16-1 and Ku 1418/3-1. We thank Pim de Klerk for the fossil pollen data, Juliane Seyfert for assistance in the field, Stefan Goen for identifying the moss species, Harrie J. M. Sipman and Arne Thell for support by identifying the lichen species, and Martin Schrön for assisting in the preparation of Fig. 3. Furthermore, we thank the organizers and participants of the 2011 POLYGON Kytalyk expedition (cf. Pestryakova and Schirrmeister, 2012) for logistic support, for assistance in the field and the kind atmosphere. We also thank the two anonymous reviewers for their constructive and helpful remarks.

\section{Appendix A. Supplementary data}

Supplementary data to this article can be found online at https:// doi.org/10.1016/j.palaeo.2018.12.019.

\section{References}

Aaby, B., 1986. Palaeoecological studies of mires. In: Berglund, B.E. (Ed.), Handbook of Holocene Palaeoecology and Palaeohydrology. Wiley, Chichester, pp. 145-164.

Abramova, A.L.A., Savicz-Ljubitakaja, L.I., Smirnova, S.N., 1961. A Guide to the Leafystemmed Mosses of Arctic USSR. Komarov Botanical Institute of the Academy of Sciences, Moscow.

Ahti, T., Stenroos, S, 2013. Cladoniaceae Nordic Lichen Flora 5, 7-117.

Bauer, I.E., Vitt, D.H., 2011. Peatland dynamics in a complex landscape: development of a fen-bog complex in the sporadic discontinuous permafrost zone of northern Alberta, Canada. Boreas 40, 714-726. https://doi.org/10.1111/j.1502-3885.2011.00210.x.

Becker, M.S., Pollard, W.H., 2016. Sixty-year legacy of human impacts on a high Arctic ecosystem. J. Appl. Ecol. 53, 876-884. https://doi.org/10.1111/1365-2664.12603.

Beermann, F., Teltewskoi, A., Fiencke, C., Pfeiffer, E.-M., Kutzbach, L., 2015. Stoichiometric analysis of nutrient availability (N, P, K) within soils of polygonal tundra. Biogeochemistry 122, 211-227. https://doi.org/10.1007/s10533-014 0037-4.

Beretta, M., Rodondi, G., Adamec, L., Andreis, C., 2014. Pollen morphology of European bladderworts (Utricularia L., Lentibulariaceae). Rev. Palaeobot. Palynol. 205, 22-30. https://doi.org/10.1016/j.revpalbo.2014.02.009.

Berggren, G., 1969. Atlas of Seeds and Small Fruits of Northwest-European Plant Species With Morphological Descriptions, 2 - Cyperaceae. Swedish Natural Science Research Council, Stockholm.

Beug, H., 2004. Leitfaden der Pollenbestimmung für Mitteleuropa und angrenzende Gebiete. Verlag Dr. Friedrich Pfeil, München.

Birks, H.H., 2001. 4. Plant macrofossils. In: Smol, J.P., Birks, H.J.B., Last, W.M. (Eds.), Tracking Environmental Change Using Lake Sediments - Terrestrial, Algal, and 
Siliceous Indicators, vol. 3. Kluwer Academic Publishers, Dordrecht, The Netherlands, pp. 49-74.

Birks, H.J.B., Birks, H.H., 1980. Quaternary Palaeoecology. Arnold, London (289 pp.).

Blok, D., Heijmans, M., Schaepman-Strub, G., Kononov, A., Maximov, T., Berendse, F., 2010. Shrub expansion may reduce summer permafrost thaw in Siberian tundra. Glob. Chang. Biol. 16, 1296-1305. https://doi.org/10.1111/j.1365-2486.2009. 02110.x.

Blundell, A., Barber, K., 2005. A 2800-year palaeoclimatic record from Tore Hill Moss, Strathspey, Scotland: the need for a multi-proxy approach to peat-based climate re constructions. Quat. Sci. Rev. 24, 1261-1277. https://doi.org/10.1016/j.quascirev. 2004.08.017.

Boike, J., Kattenstroth, B., Abramova, K., Bornemann, N., Chetverova, A., Fedorova, I. Fröb, K., Grigoriev, M., Grüber, M., Kutzbach, L., Langer, M., Minke, M., Muster, S., Piel, K., Pfeiffer, E.-M., Stoof, G., Westermann, S., Wischnewski, K., Wille, C., Hubberten, H.-W., 2013. Baseline characteristics of climate, permafrost and land cover from a new permafrost observatory in the Lena river delta, Siberia. Biogeosciences 10, 2105-2128. https://doi.org/10.5194/bg-10-2105-2013.

Boros, A., Járai-Komlódi, M., 1975. An Atlas of Recent European Moss Spores. Akadémiai Kiadó, Budapest.

Cappers, R.T.J., Bekker, R.M., Jans, J.E.A., 2006. Digitale zadenatlas van Nederland (Digital seed atlas of the Netherlands). In: Groningen Archaeological Studies. Barkhuis Publishing, Eelde; Groningen.

CAVM Team, 2003. Circumpolar Arctic Vegetation Map. Scale 1:7,500,000. Conservation of Arctic Flora and Fauna (CAFF) Map No. 1. U.S. Fish and Wildlife Service, Anchorage, Alaska.

Christensen, J.H., Krishna Kumar, K., Aldrian, E., An, S.-I., Cavalcanti, I.F.A., De Castro, M., Dong, W., Goswami, P., Hall, A., Kanyanga, J.K., Kitoh, A., Kossin, J., Lau, N.-C., Renwick, J., Stephenson, D.B., Xie, S.-P., Zhou, T., 2014. Climate phenomena and their relevance for future regional climate change. In: Stocker, T.F., Qin, D., Plattner, G.-K., Tignor, M., Allen, S.K., Boschung, J., Nauels, A., Xia, Y., Bex, V., Midgley, P.M. (Eds.), Climate Change 2013: The Physical Science Basis. Contribution of Working Group I to the Fifth Assessment Report of the Intergovernmental Panel on Climate Change. Cambridge University Press, Cambridge, UK and New York, NY, USA, pp. 1217-1308. https://doi.org/10.1017/CBO9781107415324.028.

Czerepanov, S.K., 1995. Vascular Plants of Russia and Adjacent States (the Former USSR). Cambridge University Press, Cambridge.

De Caceres, M., Jansen, F., 2016. Relationship between species and groups of sites. Package 'indicspecies', version 1.7.6. http://www.cran. r-project.org/web/ packages/indicspecies/indicspecies.pdf.

De Caceres, M., Legendre, P., Moretti, M., 2010. Improving indicator species analysis by combining groups of sites. Oikos 119, 1674-1684. https://doi.org/10.1111/j.16000706.2010.18334.x.

De Klerk, P., Donner, N., Joosten, H., Karpov, N.S., Minke, M., Seifert, N., Theuerkauf, M., 2009. Vegetation patterns, recent pollen deposition and distribution of non-pollen palynomorphs in a polygon mire near Chokurdakh (NE Yakutia, NE Siberia). Boreas 38, 39-58. https://doi.org/10.1111/j.1502-3885.2008.00036.x.

De Klerk, P., Donner, N., Karpov, N.S., Minke, M., Joosten, H., 2011. Short-term dynamics of a low-centred ice-wedge polygon near Chokurdakh (NE Yakutia, NE Siberia) and climate change during the last ca 1250 years. Quat. Sci. Rev. 30, 3013-3031. https:// doi.org/10.1016/j.quascirev.2011.06.016.

De Klerk, P., Teltewskoi, A., Theuerkauf, M., Joosten, H., 2014. Vegetation patterns, pollen deposition and distribution of non-pollen palynomorphs in an ice-wedge polygon near Kytalyk (NE Siberia), with some remarks on Arctic pollen morphology. Polar Biol. 37, 1393-1412. https://doi.org/10.1007/s00300-014-1529-3.

Donner, N., Minke, M., De Klerk, P., Sofronov, R., Joosten, H., 2012. Patterns in polygon mires in north- eastern Yakutia, Siberia: the role of vegetation and water. In: Lindholm, T., Heikkilä, R. (Eds.), Mires From Pole to Pole. The Finnish Environment, vol. 38. Edita Prima Oy, Helsinki, pp. 19-30.

Dufrene, M., Legendre, P., 1997. Species assemblages and indicator species: the need for a flexible asymmetrical approach. Ecol. Monogr. 67, 345-366. https://doi.org/10. 1890/0012-9615(1997)067[0345:SAAIST]2.0.CO;2.

Dutta, K., Schuur, E.A.G., Neff, J.C., Zimov, S.A., 2006. Potential carbon release from permafrost soils of Northeastern Siberia. Glob. Chang. Biol. 12, 2336-2351. https:// doi.org/10.1111/j.1365-2486.2006.01259.x.

Ellis, C.J., Rochefort, L., 2004. Century-scale development of polygon-patterned tundra wetland, Bylot Island $\left(73^{\circ} \mathrm{N}, 80^{\circ} \mathrm{W}\right)$. Ecology 85 (4), 963-978.

Fægri, K., Iversen, J., 1989. Textbook of Pollen Analysis. John Wiley \& Sons Ltd, Chichester, UK (328 pp.).

Foster, D.R., 1984. The dynamics of Sphagnum in forest and peatland communities in Southeastern Labrador, Canada. Arctic 37 (2), 133-140.

Frahm, J.-P., Frey, W., 1992. Moosflora, third ed. Ulmer, Stuttgart.

French, H.M., 2007. The Periglacial Environment, third ed. John Wiley and Sons, Chichester, England.

Frey, W., Frahm, J., Fischer, E., Lobin, W., 1995. Die Moos- und Farnpflanzen Europas. Fischer, Stuttgart.

Fritz, M., Wolter, J., Rudaya, N., Palagushkina, O., Nazarova, L., Obu, J., Rethemeyer, J., et al., 2016. Holocene ice-wedge polygon development in northern Yukon permafrost peatlands (Canada). Quat. Sci. Rev. 147, 279-297. https://doi.org/10.1016/j. quascirev.2016.02.008.

Gangodagamage, C., Rowland, J.C., Hubbard, S.S., Brumby, S.P., Liljedahl, A.K., Wainwright, H., Wilson, C.J., Altmann, G.L., Dafflon, B., Peterson, J., Ulrich, C., Tweedie, C.E., Wullschleger, S.D., 2014. Arctic polygonal terrain using LiDAR and NDVI data sets. Water Resour. Res. 50, 6339-6357. https://doi.org/10.1002/ 2013WR014283.

Gao, Y., Couwenberg, J., 2015. Carbon accumulation in a permafrost polygon peatland: steady long-term rates in spite of shifts between dry and wet conditions. Glob. Chang. Biol. 21, 803-815. https://doi.org/10.1111/gcb.12742.

Geocryological Map of the USSR, 1991. Scale 1:2,500,000. Moscow State University, Faculty of Geology, Department of Geocryology, Moscow.

Glavac, V., 1996. Vegetationsökologie: Grundfragen, Aufgaben, Methoden. Gustav
Fischer Verlag, Jena, Stuttgart, Lübeck, Ulm.

Godin, E., Fortier, D., Lévesque, E., 2016. Nonlinear thermal and moisture response of icewedge polygons to permafrost disturbance increases heterogeneity of high Arctic wetland. Biogeosciences 13, 1439-1452. https://doi.org/10.5194/bg-13-1439-2016. Golden Software, 2011. Surfer 11.

Golubkova, N.S., Savicz, P., Trass, H.H., 1978. Handbook of the Lichens of the U.S.S.R. 5. Cladoniaceae - Acarosporaceae. Nauka, Leningrad.

Golubkova, N.S., Dombrovskaja, A.V., Zhurbenko, M.P., Kotlov, Y.V., Krusanova, Z.G. 1996. Handbook of the Lichens of Russia. 6. Alectoriaceae, Parmeliaceae (Bryocaulon, Cetraria pr. p., Cornicularia, Dactylina, Evernia, Everniastrum, Letharia, Lethariella, Neuropogon, Pseudephebe, Pseudevernia, Usnea), Stereocaulaceae. Nauka, Sankt Petersburg.

Gornall, J., Jonsdottir, I., Woodin, R., Van der Wal, R., 2007. Arctic mosses govern belowground environment and ecosystem processes. Oecologia 153, 931-941. https://doi. org/10.1007/s00442-007-0785-0.

Grant, R.F., Mekonnen, Z.A., Riley, W.J., Arora, B., Torn, M.S., 2017. Mathematical modelling of Arctic polygonal tundra with Ecosys: 2. Microtopography determines how $\mathrm{CO}_{2}$ and $\mathrm{CH}_{4}$ exchange responds to changes in temperature and precipitation. J. Geophys. Res. Biogeosci. 122, 3174-3187. https://doi.org/10.1002/2017JG004037.

Grosse-Brauckmann, G., 1972. Über pflanzliche Makrofossilien mitteleuropäischer Torfe. I. Gewebereste krautiger Pflanzen und ihre Bestimmung. Telma 2, 19-56.

Grosse-Brauckmann, G., 1974. Über pflanzliche Makrofossilien mitteleuropäischer Torfe, II. Weitere Reste (Früchte und Samen, Moose u.a.) und ihre Bestimmungsmöglichkeiten. Telma 4, 51-117.

Hastie, T., Tibshirani, R., Friedman, J., 2009. The elements of statistical learning - data mining, inference, and prediction. In: Springer Series in Statistics, second edition. (745 pp.).

Huang, J., Zhang, X., Zhang, Q., Lin, Y., Hao, M., Luo, Y., Zhao, Z., Yao, Y., Chen, X., Wang, L., Nie, S., Yin, Y., Xu, Y., Zhang, J., 2017. Recently amplified arctic warming has contributed to a continual global warming trend. Nat. Clim. Chang. 7, 875-879. https://doi.org/10.1038/s41558-017-0009-5.

Hugelius, G., Strauss, J., Zubrzycki, S., Harden, J.W., Schuur, E.A.G., Ping, C.-L., Schirrmeister, L., Grosse, G., Michaelson, G.J., Koven, C.D., O'Donnell, J.A., Elberling, B., Mishra, U., Camill, P., Yu, Z., Palmtag, J., Kuhry, P., 2014. Estimated stocks of circumpolar permafrost carbon with quantified uncertainty ranges and identified data gaps. Biogeosciences 11, 6573-6593. https://doi.org/10.5194/bg-11. 6573-2014.

Ignatov, M.S., Afonina, O.M., Ignatova, E.A., Abolina, A., Akatova, T.V., Baisheva, E.Z., Bardunov, L.V., Baryakina, E.A., Belkina, O.A., Bezgodov, A.G., Boychuk, Ya, Cherdantseva, V.M.A., Czernyadjeva, I.V., Doroshina, G.Ya, Dyachenko, A.P., Fedosov, V.E., Goldberg, I.L., Ivanova, E.I., Jukoniene, I., Kannukene, L., Kazanovsky, S.G., Kharzinov, Z.Kh, Kurbatova, L.E., Maksimov Mamatkulov, U.K.A.I., Manakyan, V.A., Maslovsky, O.M., Napreenko, M.G., Otnyukova, T.N., Partyka, L.Ya, Pisarenko, O.Yu, Popova, N.N., Rykovsky, G.F., Tubanova, D.Ya, Zheleznova, G.V., Zolotov, V.I., 2006. Check-list of mosses of East Europe and North Asia. Arctoa 15, 1-130. https:// doi.org/10.15298/arctoa.15.01.

INKSCAPE Draw Freely, 2015. version 0.91.

Iwahana, G., 2001. http://gtnpdatabase.org/boreholes/view/221, Accessed date: 10 April 2016.

Iwahana, G., 2006. http://gtnpdatabase.org/boreholes/view/218, Accessed date: 10 April 2016.

Janssen, C.R., 1966. Recent pollen spectra from the deciduous and coniferous - deciduous forest of northeastern Minnesota: a study in pollen dispersal. Ecology 47, 804-825.

Joosten, H., De Klerk, P., 2002. What's in a name? Rev. Palaeobot. Palynol. 122, 29-45. https://doi.org/10.1016/S0034-6667(02)00090-8.

Kärnefelt, I., 1979. The brown fruticose species of Cetraria. Opera Botanica 46, 1-150.

Kärnefelt, I., 1986. The genera Bryocaulon, Coelocaulon and Cornicularia and formerly associated taxa. Opera Botanica 86, 1-90.

Kärnefelt, I., Thell, A., 1996. A new classification for the Dactylina/Dufourea complex. Nova Hedwigia 62, 487-511.

Kärnefelt, I., Mattsson, J.-E., Thell, A., 1993. The lichen genera Arctocetraria, Cetraria and Cetrariella (Parmeliaceae) and their presumed evolutionary affinities. Bryologist 96, 394-404.

Katz, N.J., Katz, S.W., Kipiani, M.G., 1965. Atlas i opredelitel plodow i semjan, wstretschajuschtschichsa w tschetwertutschnych otloshenijach SSSR. Nauka, Moscow.

Katz, N.J., Katz, S.W., Skobejewa, E.I., 1977. Atlas rastitelnich ostakow w torfach. Nedra, Moskow.

Klinger, P.U., 1986. Feinstratigraphische Untersuchungen an Hochmooren. (Dissertation Kiel, 135 pp.).

Konstantinova, N.A., Bakalin, V.A., 2009. Checklist of liverworts (Marchantiophyta) of Russia. Arctoa 18, 1-64. https://doi.org/10.15298/arctoa.18.01.

Körber-Grohne, U., 1964. Bestimmungsschlüssel für subfossile Juncus-Samen und Gramineen-Früchte. Probleme der Küstenforschung 7, 47.

Koska, I., Succow, M., Clausnitzer, U., Timmermann, T., Roth, S., 2001. Vegetationskundliche Kennzeichnung von Mooren (topische Betrachtung). In: Succow, M., Joosten, H. (Eds.), Landschaftsökologische Moorkunde. Schweizerbart, Stuttgart, pp. 112-184.

Kotowski, W., van Diggelen, R., Kleinke, J., 1998. Behaviour of wetland plant species along a moisture gradient in two geographically distant areas. Acta Botanica Neerlandica 47, 337-349.

Koven, C.D., Ringeval, B., Friedlingstein, P., Ciais, P., Cadule, P., Khvorostyanov, D., Krinner, G., Tarnocai, C., 2011. Permafrost carbon-climate feedbacks accelerate global warming. Proc. Natl. Acad. Sci. U. S. A. 108, 14769-14774. https://doi.org/ 10.1073/pnas.1103910108.

Kuc, M., 1974. The interglacial flora of Worth Point, Western Banks Island. In: Geological Survey of Canada, 74-1B, pp. 227-231.

Leyer, I., Wesche, K., 2007. Multivariate Statistik in der Ökologie. Springer-Verlag, Berlin, Heidelberg.

Liljedahl, A.K., Boike, J., Daanen, R.P., Fedorov, A.N., Frost, G.V., Grosse, G., Hinzman, L.D., Iijma, Y., Jorgenson, J.C., Matveyeva, N., Necsoiu, M., Raynolds, M.K., 
Romanovsky, V.E., Schulla, J., Tape, K.D., Walker, D.A., Wilson, C.J., Yabuki, H., Zona, D., 2016. Pan-Arctic ice-wedge degradation in warming permafrost and its influence on tundra hydrology. Nat. Geosci. 9, 312-318. https://doi.org/10.1038/ ngeo 2674 .

Londo, G., 1976. The decimal scale for releves of permanent quadrats. Vegetatio 33, 61-64. https://doi.org/10.1007/BF00055300.

Longton, E.R., 1988. The Biology of Polar Bryophytes and Lichens. Cambridge University Press, Cambridge.

Magyari, E., Buczkó, K., Jakab, G., Braun, M., Pál, Z., Karátson, D., Pap, I., 2009. Palaeolimnology of the last crater lake in the Eastern Carpathian Mountains: a multiproxy study of Holocene hydrological changes. Hydrobiologia 631, 29-63. https://doi.org/10.1007/s10750-009-9801-1.

Michaelis, D., 2011. Die Sphagnum-Arten der Welt. Bibl. Bot. 160, 1-408.

Minke, M., Donner, N., Karpov, N.S., De Klerk, P., Joosten, H., 2007. Distribution, diversity, development and dynamics of polygon mires: examples from Northeast Yakutia (Siberia). Peatland Int. 2007 (1), 36-40.

Minke, M., Donner, N., Karpov, N.S., De Klerk, P., Joosten, H., 2009. Patterns in vegetation composition, surface height and thaw depth in polygon mires in the Yakutian Arctic (NE Siberia): a microtopographical characterisation of the active layer. Permafr. Periglac. 20, 357-368. https://doi.org/10.1002/ppp.663.

Moore, P.D., Webb, J.A., Collinson, M.E., 1991. Pollen analysis, 2nd Edn. Blackwell Science, Oxford.

Nauta, A.L., Heijmans, M.P.D., Blok, D., Limpens, J., Elberling, B., Gallagher, A., Li, B. Petrov, R.E., Maximov, T.C., Van Huissteden, J., Berendse, F., 2015. Permafrost collapse after shrub removal shifts tundra ecosystem to a methane source. Nat. Clim. Chang. 5, 67-70. https://doi.org/10.1038/nclimate2446.

Nelson, F.E., Hinkel, K.M., Shiklomanov, N.I., Walker, D.A., 1998. Active-layer thickness in north central Alaska: Systematic sampling, scale, and spatial autocorrelation. J. Geophys. Res. 103 (D22), 28963-28973 (http://doi.org/).

Nilsson, T., 1952. Kvartärpaleontologi och Kvartärpaleontologiska undersökningsmetoder. 2. Lunds Universitet, pp. 238 (+ 63 Plates).

Nilsson, Ö., Hjelmqist, H., 1967. Studies on the nutlet structure of South Scandinavian species of Carex. Bot. Notiser 120, 460-485.

NOAA, 2015. Arctic Report Card: update for 2015. http://www.arctic.noaa.gov/ reportcard/, Accessed date: 10 April 2016.

O'Donnell, J.A., Romanovsky, V.E., Harden, J.W., McGuire, A.D., 2009. The effect of moisture content on the thermal conductivity of moss and organic soil horizons from black spruce ecosystems in interior Alaska. Soil Sci. 174, 646-651.

Oksanen, J., Blanchet, F.G., Friendly, M., Kindt, R., Legendre, P., McGlinn, D., Minchin, P.R., O'Hara, R.B., Simpson, G.L., Solymos, P., Stevens, M.H.H., Szoecs, E., Wagner, H., 2016. vegan: community ecology package. R package version $2.4-1$. https:// CRAN.R-project.org/package = vegan.

Orange, A., James, P.W., White, F.J., 2001. Microchemical methods for the identification of lichens. British Lichen Society, London.

Pestryakova, L., Schirrmeister, L., 2012. Introduction. In: Schirrmeister, L., Pestryakova, L., Wetterich, S., Tumskoy, V. (Eds.), Joint Russian-German Polygon Project East Siberia 2011-2014: The Expedition Kytalyk 2011. Berichte zur Polar- und Meeresforschung (Reports on Polar and Marine Research). vol. 653. Alfred Wegener Institute for Polar and Marine Research, Bremerhaven, pp. 1-4. http://hdl.handle. net/10013/epic.40369.

Petrescu, A.M.R., Van Huissteden, J., Jackowicz-Korczynski, M., Yurova, A., Christensen, T.R., Crill, P.M., Bäckstrand, K., Maximov, T.C., 2008. Modeling $\mathrm{CH}_{4}$ emissions from Arctic wetlands: effects of hydrological parameterization. Biogeosciences 5, 111-121. https://doi.org/10.5194/bg-5-111-2008.

Polunin, N., 1959. Circumpolar Arctic Flora. Oxford University Press, Oxford.

R Core Team, 2013. R: A Language and Environment for Statistical Computing. R Foundation for Statistical Computing, Vienna, Austria URL. http://www.R-project. org/.

Rivas-Martínez, S., 2007. Global Bioclimatics, Data Set. Phytosociological Research Center, Madrid, Spain. http://www.globalbioclimatics.org, Accessed date: 10 April 2016.

Rothmaler, W., 2002. Exkursionsflora von Deutschland Gefäßpflanzen: Grundband Spektrum Akademischer Verlag, Heidelberg.

Schmidtlein, S., Tichý, L., Feilhauer, H., Faude, U., 2010. A brute-force approach to vegetation classification. J. Veg. Sci. 21, 1162-1171. https://doi.org/10.1111/j.1654 1103.2010.01221.x.

Schneider, A., Wetterich, S., Schirrmeister, L., Herzschuh, U., Meyer, H., Pestryakova, L.A., 2016. Freshwater ostracods (Crustacea) and environmental variability of polygon ponds in the tundra of the Indigirka Lowland, North-East Siberia. Polar Res. 35, 1-22. https://doi.org/10.3402/polar.v35.25225.

Schultz, J., 1995. Die Ökozonen der Erde. Verlag Eugen Ulmer, Stuttgart.

Sernander, R., 1918. Subfossile Flechten. Flora, Jena 112, 703-724.

Sitte, P., Weiler, E.W., Bresinsky, A., Kadereit, J.W., Körner, C., 2002. StrasburgerLehrbuch der Botanik, 35th ed. Spektrum Akademischer Verlag, Heidelberg, Berlin.

Smith, A.J.E., 1980. The Moss Flora of Britain and Ireland. Cambridge University Press, Cambridge.

Streletskiy, D.A., Sherstiukov, A.B., Frauenfeld, O.W., Nelson, F.E., 2015. Changes in the 1963-2013 shallow ground thermal regime in Russian permafrost regions. Environ. Res. Lett. 10, 125005

Tallis, J.H., 1962. The identification of Sphagnum spores. Trans. Br. Bryological Soc. 4, 209-213.

Tarnocai, C., 1999. The effect of climate warming on the carbon balance of cryosols in
Canada. Permafr. Periglac. 10, 251-263. https://doi.org/10.1002/(SICI)10991530(199907/09)10:3<251::AID-PPP323 > 3.0.CO;2-5.

Teltewskoi, A., Seyfert, J., Joosten, H., 2012. Records from the model polygon Lhc-11 for modern and palaeoecological studies. In: Schirrmeister, L., Pestryakova, L., Wetterich, S., Tumskoy, V. (Eds.), Joint Russian-German Polygon Project East Siberia 2011-2014: The Expedition Kytalyk 2011. Berichte zur Polar- und Meeresforschung (Reports on Polar and Marine Research). vol. 653. Alfred Wegener Institute for Polar and Marine Research, Bremerhaven, pp. 51-60. http://hdl.handle.net/10013/epic. 40369.

Teltewskoi, A., Beermann, F., Beil, I., Bobrov, A., De Klerk, P., Lorenz, S., Lüder, A., Michaelis, D., Joosten, H., 2016. 4000 years of changing wetness in a permafrost polygon peatland (Kytalyk, NE Siberia): a comparative high-resolution multi-proxy study. Permafr. Periglac. 27, 76-95. https://doi.org/10.1002/ppp.1869.

Ter Braak, C.J.F., 1986. Canonical Correspondence Analysis: a new eigenvector technique for multivariate direct gradient analysis. Ecology 67, 1167-1179. https://doi.org/10 $2307 / 1938672$.

Thomson, J.W., 1984. American Arctic Lichens. I. Macrolichens. Columbia University Press, New York.

Tolmachev, A.I., 1974. Opredelitel' vysshikh rasteniy Yakutii. Nauka, Novosibirsk.

Tolonen, K., 1971. On the regeneration of northeuropean bogs I. Klaukkalan Isosuo in S. Finland. Acta Agralia Fennica 123, 143-166.

Tolonen, K., Huttunen, P., Jungner, H., 1985. Regeneration of two coastal raised bogs in eastern North America. In: Annales Academiae Scientiarum Fennicae Ser A III, pp. 139 (51 p.).

Tumskoy, V., Schirrmeister, L., 2012. Study area, geological and geographical characteristics. In: Schirrmeister, L., Pestryakova, L., Wetterich, S., Tumskoy, V. (Eds.), Joint Russian-German Polygon Project East Siberia 2011-2014: The Expedition Kytalyk 2011. Berichte zur Polar- und Meeresforschung (Reports on Polar and Marine Research). vol. 653. Alfred Wegener Institute for Polar and Marine Research, Bremerhaven, pp. 5-10. http://hdl.handle.net/10013/epic.40369.

Urbanavichus, G., 2010. A Checklist of the Lichen Flora of Russia. Nauka, St. Petersburg.

Väliranta, M., Korhola, A., Seppä, H., Sarmaja-korjonen, K., Laine, J., Alm, J., 2007. Highresolution reconstruction of wetness dynamics in a southern boreal raised bog, Finland, during the late Holocene: a quantitative approach. The Holocene 17 (8), 1093-1107. https://doi.org/10.1177/0959683607082550.

Väliranta, M., Blundell, A., Charman, D.J., Karofeld, E., Korhola, A., Sillasoo, Ü., Tuittila, E.-S., 2012. Reconstructing peatland water tables using transfer functions for plant macrofossils and testate amoebae: a methodological comparison. Quat. Int. 268 , 34-43. https://doi.org/10.1016/j.quaint.2011.05.024.

Van der Knaap, W.O., Aptroot, A., Oosterveld, P., 1989. A 7500-year-old record of Peltigera aphthosa from Spitsbergen. Lichenologist 21, 90-91. https://doi.org/10 1017/S0024282989000125.

Van der Molen, M.K., Van Huissteden, J., Parmentier, F.J.W., Petrescu, A.M.R., Dolman, A.J., Maximov, T.C., Kononov, A.V., Karsanaev, S.V., Suzdalov, D.A., 2007. The growing season greenhouse gas balance of a continental tundra site in the Indigirka lowlands, NE Siberia. Biogeosciences 4, 985-1003. https://doi.org/10.5194/bg-4985-2007.

Vaughn, L.J.S., Conrad, M.E., Bill, M., Torn, M.S., 2016. Isotopic insights into methane production, oxidation, and emissions in Arctic polygon tundra. Glob. Chang. Biol. 22, 3487-3502. https://doi.org/10.1111/gcb.13281.

Vitikainen, O., 1994. Taxonomic revision of Peltigera (lichenized Ascomycotina) in Europe. Acta Bot. Fenn. 152, 1-96.

Wainwright, H.M., Dafflon, B., Smith, L.J., Hahn, M.S., Curtis, J.B., Wu, Y., Ulrich, C. Peterson, J.E., Torn, M.S., Hubbard, S.S., 2015. Identifying multiscale zonation and assessing the relative importance of polygon geomorphology on carbon fluxes in an Arctic tundra ecosystem. J. Geophys. Res. Biogeosci. 120, 788-808. http://doi:10. 1002/2014JG002799.

Waller, M., Carvalho, F., Grant, M.J., Bunting, M.J., Brown, K., 2017. Disentangling the pollen signal from fen systems: modern and Holocene studies from southern and eastern England. Rev. Palaeobot. Palynol. 238, 15-33. https://doi.org/10.1016/j. revpalbo.2016.11.007.

Westhoff, V., Van der Maarel, E., 1973. The Braun-Blanquet approach. In: Whittaker, R.H. (Ed.), Handbook of Vegetation Science, Part 5, Classification and Ordination of Communities. Junk, Den Haag, pp. 617-726.

Wolter, J., Lantuit, H., Fritz, M., Macias-Fauria, M., Myers-Smith, I., Herzschuh, U., 2016 Vegetation composition and shrub extent on the Yukon coast, Canada, are strongly linked to ice-wedge polygon degradation. Polar Res. 35, 27489. https://doi.org/10. 3402/polar.v35.27489.

Zhurbenko, M.P., Laursen, G.A., Walker, D.A., 2005. New and rare lichenicolous fungi and lichens from the North American Arctic. Mycotaxon 92, 201-212.

Zibulski, R., Herzschuh, U., Pestryakova, L.A., Wolter, J., Müller, S., Schilling, N., Wetterich, S., Schirrmeister, L., Tian, F., 2013. River flooding as a driver of polygon dynamics: modern vegetation data and a millennial peat record from the Anabar River lowlands (Arctic Siberia). Biogeosciences 10, 5703-5728. https://doi.org/10. 5194/bg-10-5703-2013.

Zibulski, R., Herzschuh, U., Pestryakova, L.A., 2016. Vegetation patterns along microrelief and vegetation type transects in polygonal landscapes of the Siberian Arctic. J. Veg. Sci. 27, 377-386. https://doi.org/10.1111/jvs.12356.

Zimmermann, C., Lavoie, C., 2001. A paleoecological analysis of a southern permafrost peatland, Charlevoix, Quebec. Can. J. Earth Sci. 38, 909-919. https://doi.org/10. 1139/cjes-38-6-909. 